\title{
小中員環状アヌレノンおよび関連化合物の化学
}

\author{
海老根誠治*・恒 次丈 介 $^{*}$ ・佐 藤 勝*
}

The Chemistry of Small- and Medium-Ring Annulenones and Related Compounds

Seiji Ebine*, Josuke Tsunetsugu* and Masaru Sato*

はじめに

平面単環状の共役不飽和炭化水素をアヌレンといい, 対応するケトンをアヌレノン(1)という(Sondheimer) ${ }^{1)}$ 。 カルボニル酸素の電子吸引性のために $(4 \mathrm{n}+3)$ 員環ア ヌレノンは芳香族的 $(4 \mathrm{n}+2) \pi$ 電子系となり, $(4 \mathrm{n}+1)$

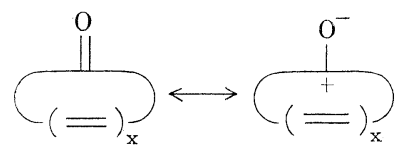

(1)

員環アヌレノンは非芳族的 $4 \mathrm{n} \pi$ 電子系となる (Sondheimer は “非芳香族”といい，“芳香族”といら言葉 は使っていない)。

従来芳香族化合物とはベンゼンのように化学反応上安 定な環状共役不飽和分子, 芳香族性とは基底状態の熱力 学的安定性 (低いエンタルピー) と定義されてきた ${ }^{2)}$ (こ の 2 つの定義は芳香族性の有無大小について必ずしも同 一の結果を与えるものではない) が，近年 Dewar ら ${ }^{3 a)}$ は分子軌道理論 (SCF-LCAO-MO) の立場から 非局在 化エネルギーを定量的目安として芳香族性を論じ，これ が有機化学者に受け入れられ易いところから広く使われ るようになった。しかし芳香族性の定義は厳密にすれば するほど包含できる範囲が狭くなり，共鳴エネルギー， スペクトル的性質, 化学反応性の 3 つを簡単な芳香族性 の定義で同時にかつ広く統一的に説明することはますま

* 埼玉大学理工学部化学科

* Department of Chemistry, Faculty of Science and Engineering, Saitama University
すむずかしくなるように思わ机る4)。ここでは Dewar ${ }^{3)}$ や Breslow ${ }^{\text {aa }}$ にしたがって次のように定義することに する。

1）共鳴エネルギーが比較的大きい正の值の化合物は 芳香族

2）共鳴エネルギーがゼロに近い化合物は非芳香族

3）共鳴エネルギーが負の值になる化合物は反芳香 族（“反芳香族”については批判もある

第二次大戦中から戦後にかけて, Dewar ら，野副鉄 男教授一門, Doering らが，従来の芳香族理論に対して 見事な実験的根拠を与えたので，これが契機となって非 ベンゼン系芳香族化学の分野が開け，今ではシクロプロ ペニウムカチオンから 20 数員環アヌレンにいたるまで の種々の $\pi$ 電子系について, 芳香族, 擬芳香族, 反芳香 族, ホモ芳香族, 超芳香族など多样の芳香族性が議論さ れるようになった。これらの芳香族化学は理論と実験が 緊密に作用しあって発展した顕著な例であって，化学の 中でも特に魅力ある分野と考えられる。以下には非ベン ゼン系芳香族化学の一部分である小, 中員環状アヌレノ ンおよび関連化合物の化学を紹介する(10員環以上の大 環状アヌレノンについては別に綜説がある ${ }^{1,6) 。}$

\section{I. シクロプロペノン}

シクロプロペニウムカチオン $(2 \mathrm{a})$ は $(4 \mathrm{n}+2) \pi$ 則の $\mathrm{n}=0$ の場合に当るもっとも簡単な芳香族化合物である。 Breslow らにより初めトリフェニルシクロプロペニウム カチオン (2b) が合成され, 後で母体 (2a) が合成され て性質が検討された。(2b) の $D E$ (非局在化エネルギ 一) は $9.19 \beta$ であって, 3 個のベンゼンの $D E 6 \beta$ よ り $3.19 \beta$ 大であり，またトリフェニルメチルカチオン 
(3) の $D E 7.80 \beta$ より $1.39 \beta$ 大である。(2b) と (3) の性質の比較を 表 1 に掲げたが，表の数值は（2b）の 安定性を示している。シクロプロペニウムカチオンの NMR（アセトニトリル中）は $\delta 11.1 〜 11.2$ の極めて低 磁場に鋭い一重線を示すので，正電荷が 3 つの炭素に均 等に非局在化していることがわかる。

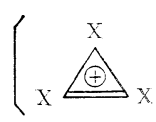<smiles>C1CCCC1</smiles>

(2)

a, $\mathrm{X}=\mathrm{H} ; \mathrm{b}, \mathrm{X}=\mathrm{P}$ $\mathrm{Y}^{-}=\mathrm{SbCl}_{6}^{-}, \mathrm{AlCl}_{4}^{-}, \mathrm{BF}_{4}^{-}$

表 1 $^{\mathrm{a} a}$ ) トリフェニルトロピリウムカチオンとトリフ エニルメチルカチオンの性質比較

\begin{tabular}{l|cc}
\hline & & \\
& &
\end{tabular}

シクロプロペノン（4a）はもっとも簡単なアヌレノン であり，大きい環歪みを持つにもかかわらず，シクロプ ロペニウムカチオン類似の双極イオン構造 (4'a) の寄与 による $\pi$ 共役安定化 $(D E=1.36 \beta)$ が期待される化合 物である。Breslow らは初めジフェニルシクロプロペノ ン (4b) を合成し，後に (4a) 自身を溶液として合成し, さらに 1972 年に (4a) を純粋に単離した ${ }^{9 \mathrm{c})}$ 。(4a) は 融点 $\left(\mathrm{mp}-29 \sim-28^{\circ} \mathrm{C}\right)$ 以下で数週間安定, IR $\left(\mathrm{CH}_{2}\right.$ $\left.\mathrm{Cl}_{2}\right)$ 1870, $1835 ;\left(\mathrm{H}_{2} \mathrm{O}\right) 1850 \mathrm{~cm}^{-1}, \mathrm{NMR}\left(\mathrm{CDCl}_{3}\right) \delta$ 9.08 ，硫酸を加えると (4'a) となり， $\delta 9.61$ となる。

$\mathrm{CDCl}_{3}$ 中で $\mathrm{J}^{13} \mathrm{C}-\mathrm{H}=217, \mathrm{~J}_{\mathrm{HH}}=3.9 \mathrm{~Hz}$ (2 個のHは 等価であるが ${ }^{13} \mathrm{C}$ サテライトシグナルから $\mathrm{J}_{\mathrm{HH}}$ が求ま る), 硫酸中では $\mathrm{J}^{13} \mathrm{C}-\mathrm{H} 250, \mathrm{~J}_{\mathrm{HH}}=1.3 \mathrm{~Hz}$ である。 $\mathrm{J}^{13} \mathrm{C}-\mathrm{H}$ の值はオレフィンとしては。異常に大きな值であ り，ことに硫酸中の值は (2a) の $\mathrm{J}^{13} \mathrm{C}-\mathrm{H}=265, \mathrm{~J}_{\mathrm{HH}} \leq$ $0.25 \mathrm{~Hz}$ に近い。したがってシクロプロペノンの構造は ことに硫酸中ではシクロプロペニウムカチオンに類す る。(シクロプロペニウムカチオンは $\mathrm{J}^{13} \mathrm{C}-\mathrm{H}$ の值から C$\mathrm{H}$ 結合がアセチレン類似の $s p$ 軌道であり, C-C 結合は $s p^{3}$ 軌道による bent $s$ 結合と $p$ 軌道による $\pi$ 結合とか らできていると考えられている)。シクロプロペノン類 の IR は一般に $1870 \sim 1800 \mathrm{~cm}^{-1}$ と $1660 \sim 1600 \mathrm{~cm}^{-1}$ の 2 本の強、特徵的な吸収を示す（表 2,3)。MO 計算に よる電子構造，双極子モーメントなどを表 4, 図 1 に示 した。シクロプロペノン類は 2 量化しやすく, ジクロル<smiles>[X]c1cc1=O</smiles>

(4)

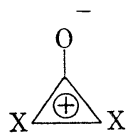

$\left(4^{\prime}\right)$

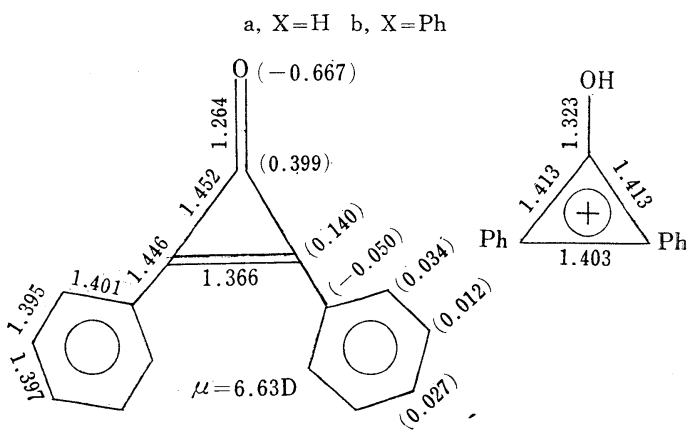

図 1 ジフェニルシクロプロペノン, ジフェニルシク ロプロペニウムカチオンの計算結合距離 $(\AA ⿻$,力 ッ キなし数字, $\mathrm{MO})^{3 \mathrm{~b})} \pi$ 電子密度 (カッユ内 数字), 双極子能率 $(\mathrm{SCF}-\mathrm{MO})^{11)}$

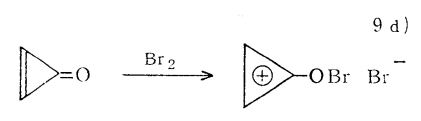

(5)

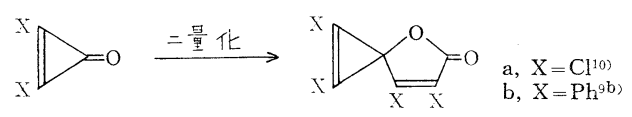

(6)

表 2 ジ置換シクロプロペノン $(4)^{9 \mathrm{~b})}$

\begin{tabular}{l|l|r|r}
\hline \multicolumn{1}{c|}{$\mathrm{X}$} & \multicolumn{1}{c|}{$\mathrm{IR}\left(\mathrm{CCl}_{4}, \mathrm{~cm}^{-1}\right)$} & $\mu(\mathrm{D})$ & \multicolumn{1}{c}{$\mathrm{p} K_{\mathrm{a}}$} \\
\hline $\mathrm{Me}$ & $1866,1848,1657$ & - & -1.5 \\
$n-\mathrm{Pr}$ & 1840,1630 & 4.78 & -1.9 \\
$\mathrm{Ph}$ & 1852,1639 & 5.14 & $-2.5,-3.2$ \\
\hline
\end{tabular}

表 3 シクロプロペノン類の振動の位置エネルギー分布 ${ }^{12}$

\begin{tabular}{c|l|l|l}
\cline { 2 - 4 } \multicolumn{1}{c|}{} & \multicolumn{1}{c|}{$\mathrm{C}=\mathrm{O}$} & $\mathrm{C}=\mathrm{C}$ & $\mathrm{C}-\mathrm{C}$ (環) \\
\hline $1850 \mathrm{~cm}^{-1}$ (IR) & $40 \sim 50 \%$ & $10 \sim 20 \%$ & $30 \sim 35 \%$ \\
$1640 \mathrm{~cm}^{-1}$ (IR) & $20 \sim 30$ & $55 \sim 60$ & 0 \\
$880 \mathrm{~cm}^{-1}$ (Raman) & $15 \sim 20$ & 15 & $55 \sim 65$ \\
\hline
\end{tabular}

表 4 シクロプロペノンの電子構造

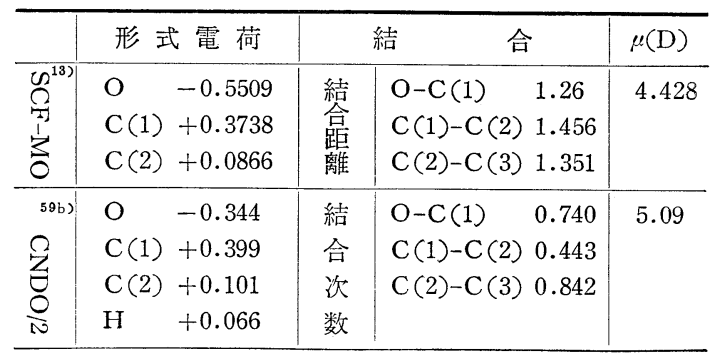


(表4の続き)

\begin{tabular}{|c|c|c|c|c|c|}
\hline \multirow{3}{*}{$\begin{array}{l}14) \\
5 \\
2 \\
0 \\
1\end{array}$} & & 子 & 密 & & \multirow{6}{*}{3.58} \\
\hline & & $(\sigma)$ & $(\pi)$ & (全) & \\
\hline & $\mathrm{O}$ & 7.019 & 1.363 & 8.382 & \\
\hline \multirow{3}{*}{$\begin{array}{l}3 \\
3 \\
3 \\
3 \\
3 \\
3\end{array}$} & $\mathrm{C}(1)$ & 4.710 & 0.815 & 5.525 & \\
\hline & $\mathrm{C}(2)$ & 5.451 & 0.911 & 6.362 & \\
\hline & $\mathrm{H}$ & 0.684 & - & 0.684 & \\
\hline
\end{tabular}

表 5 環状エノロンの $\mathrm{p} K_{\mathrm{a}}{ }^{15)}$

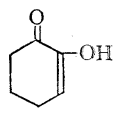

10.3<smiles>O=C1CCC=C1O</smiles>

9.1

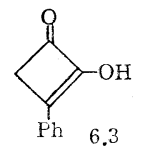

6.3

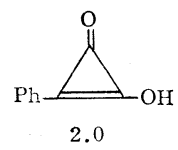

(4c)
体は常温で二量体 (6a) になる10)。(4a) は臭素と反応す ると付加しないでシクロプロペニウム塩 (5)を与える。 （4b）は塩基性が強く安定な臭化水素酸塩および Lewis 酸 $\left(\mathrm{BF}_{3}, \mathrm{SbCl}_{5}\right)$ 塩を与え, (4b) の双極子モーメント $5.08 \mathrm{D}$ はベンゾフェノンの $2.97 \mathrm{D}$ より大きく ${ }^{\mathrm{a} a)}$, 熱的 に安定で $120^{\circ} \mathrm{C}$ まで変化しない。ただしトルエン中長く 加熱すると二量体 (6b) になり, また $130 \sim 140^{\circ} \mathrm{C}$ で分 解してジフェニルアセチレンと一酸化炭素になる。これ らの性質はシクロプロペノン類が特殊な安定構造をむつ ことを示している。フェニルシクロプロペノロン (4c) はカルボン酸ビニログであって単なるエノロンより酸性 が強い（表 5)。(4c) とそのメチルエーテルは UV がほ とんど同じであるから，(4c) はジケトン型でなくエノ ロン型で存在していることがわかる。これはシクロプロ ペノン構造の安定性を示すものである。

比較としてシクロプロパノン（7) は $\mu$ (ASMO-SCF 計算) $2.16 \mathrm{D}^{16)}$ ，不安定な化合物で室温でただちに重合 する ${ }^{17)}$ 。

$$
\mathrm{CH}_{2}=\mathrm{C}=\mathrm{O} \underset{\mathrm{CH}_{2} \mathrm{~N}_{2}, \mathrm{CH}_{2} \mathrm{Cl}_{2}}{-78^{\circ} \mathrm{C}} \stackrel{\mathrm{O}}{\longrightarrow} \text { (収率 } 90 \% \text { ) }
$$

(7)

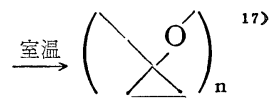

ベンゾシクロプロペノン $(8)$ は $\left(8^{\prime}\right)$ のよらな $(4 \mathrm{n}+$ 2) $\pi$ 系 7 員環状芳香族的構造が考光られる。ベンゾシク ロプロペン (9)よりも環の歪みが大きいが $\pi$ 電子共役安

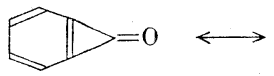

(8)

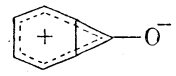

(8)

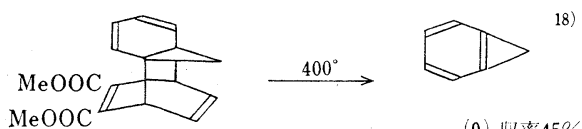

(9) 收率 $45 \%$

定化が期待される。その存在は下記のように認められて

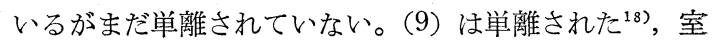
温で数週間安定。

環状ケトン，キノン，その他の化合物の MS における フラグメントイオンとしてシクロプロペノンカチオン (4e), ベンゾシクロプロペノンカチオン (8a), ベンゾ シクロプロペニルカチオン $(9 \mathrm{a})$, の生成が報告されてい る。

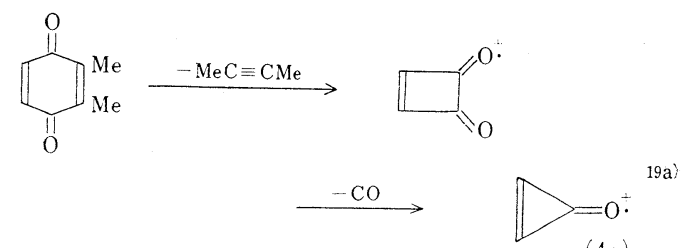

* ンクロプロペノン類の主な合成反応

$: \mathrm{CCl}_{2}$ $\mathrm{CHCl}=\mathrm{CCl}_{3}$<smiles>CCCCCCCCC1C(Cl)C1Cl</smiles><smiles>OCCO</smiles><smiles>ClC1C(Cl)C1Cl</smiles>

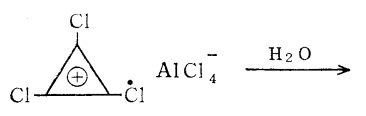<smiles>O=c1c(Cl)c1Cl</smiles>

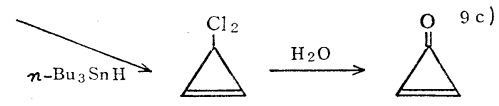

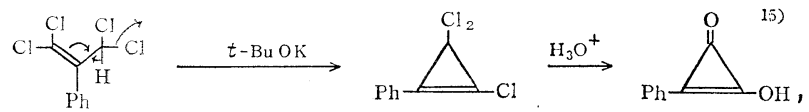

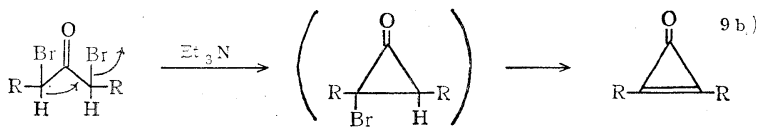




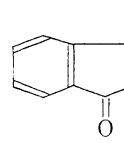

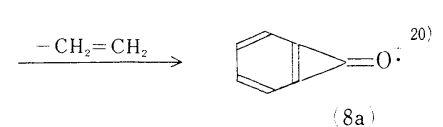

(8a)

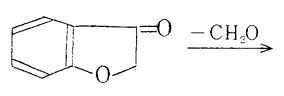

$-\mathrm{CO}$

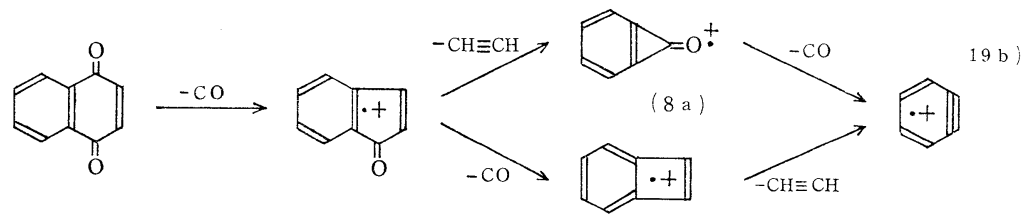

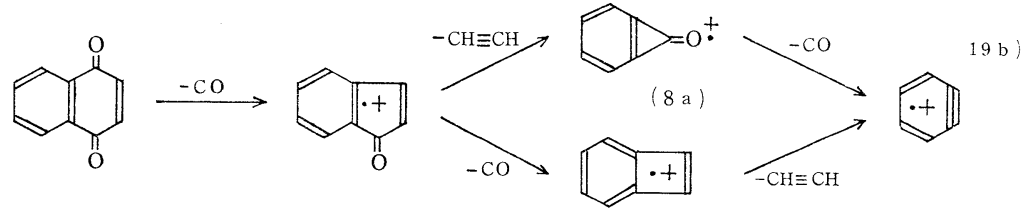

$19 \mathrm{~b})$<smiles></smiles>

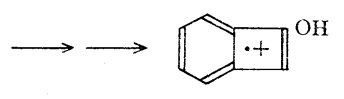<smiles>C1CC1</smiles><smiles>[C+]1C2C=CC1C2</smiles>

(9a)

3-アミノベンゾトリアジン-4-オン誘導体 (10) をメ夕 ノール中で光分解すると $p$-置換安息香酸メチルを生じ, (10）をアントラセンの存在下に熱 分解するとトリプチ センを生ずる ${ }^{22)}$ 。(10) の類似体 (11a), (11b) をメタノ 一ル中で弱く酸化するとどちらからも $m$-および $p$-置 換安息香酸メチルを生じる (表 6)。これらの反応は中 閒にベンゾシクロプロペノン $(8,8 \mathrm{~b}, 8 \mathrm{c})$ を経るものと 考光られている2,23)。

表 6 ベンゾトリアジノンの分解 ${ }^{28}$

\begin{tabular}{c|c|c}
\hline トリアジノン & \multicolumn{2}{|c}{ 安急香酸メチルの収率 $(\%)$} \\
\hline (11a) & COOMe & COOMe \\
$\mathrm{X}=\mathrm{Cl}$ & 58 & 11 \\
$\mathrm{NO}_{2}$ & 59 & 9 \\
$\mathrm{Me}$ & 57 & \\
(11b) & & 68 \\
$\mathrm{X}=\mathrm{Cl}$ & 0 & 73 \\
$\mathrm{NO}_{2}$ & 7 & \\
\hline
\end{tabular}

シクロプロペノンは単離され，そのジフェニル誘導体 はかなり安定なのに反し，ベンゾシクロプロペノンがき わめて不安定であるのは, シクロプロペノン環の共鳴エ ネルギーがベンゼンと縮環することにより失われ，かつ 環の歪みが増大するためと思われる。

\section{II. シクロブテンジオン（シクロブタジ エノキノン)}

シクロブタジエン (12) はきわめて不安定な化合物で, 寿命は $t \frac{1}{2}=2 \sim 10 \mathrm{~ms}$ と報告されている ${ }^{24}$ (ただし鉄卜 リカルボニル錯体 (12a) は安定 $\left.{ }^{25}\right)$ 。シクロブタジエニ ルジカチオン (13) は $(4 \mathrm{n}+2) \pi$ 系の $\mathrm{n}=0$ の場合にあ たり，その誘導体 $(13 \mathrm{~b})^{26)}$ が合成されている。シクロ ブタジエノキノン(シクロブテンジオン) (14) はシクロ ブタジエニルカチオン (13) に類する構造 (14'，14", 14"') の寄与をうけると考光られる。表 7 を見ると， 鎖状と 6 員環状共役系では $\mathrm{X}=\mathrm{CH}_{2}$ よりも $\mathrm{X}=\mathrm{O}$ の方 が $D E$ が小さいのに, 3 員環と 4 員環では $\mathrm{X}=\mathrm{CH}_{2}$ よ

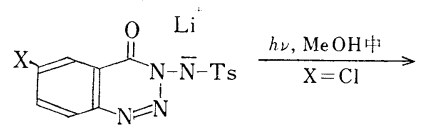

10) $\frac{220^{\circ} \mathrm{C}, \text { トリグリム中 }}{\mathrm{X}=\mathrm{H}}$

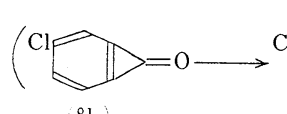

$8 \mathrm{~b}$<smiles>OC1(O)C2CC1(O)C1C=CC2C1</smiles>

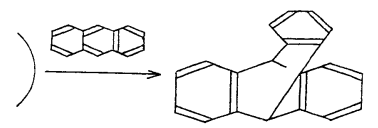
22 $4 x+30 \%$

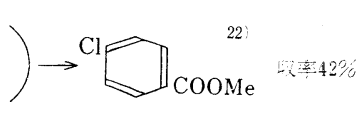<smiles>C1=Cc2ccccc2C2C3CCC(CC3)C2O1</smiles><smiles>[X]c1ccc2c(c1)C(=O)c1cc(C(C)C)ccc1-2</smiles>

(8c) (11a)

(11b) 

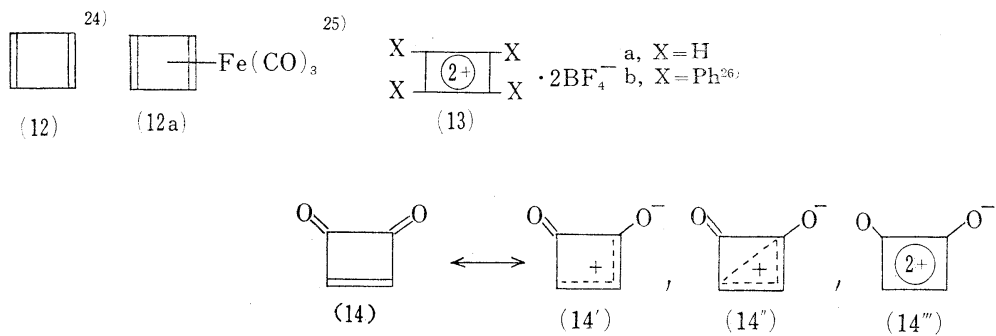

りも $\mathrm{X}=\mathrm{O}$ の方が $D E$ が大きい。これはシクロプロペ ノン (4a) と (14) が $(4 \mathrm{n}+2) \pi$ 系の安定性をもつこ とを示すすのである ${ }^{27 b) 。 ま す ゙ フ ェ ニ ル シ ク ロ フ ゙ タ シ ゙ エ ~}$ ノキノン (15 $)^{27 \mathrm{a}, \mathrm{b})}$ が合成され, 次にジフェニルシク ロブタジエノキノン $(16)^{28)}$ が合成された。

シクロブタジエノキノン自身(14) は最近合成された。 $\mathrm{NMR}\left(\mathrm{CCl}_{4}\right) \quad 0.27 \tau$ で, 異常に低い $\tau$ 值は極性構造 $\left(14^{\prime \prime}, 14^{\prime \prime \prime}\right)$ の寄与を示す ${ }^{29)}$ 。四角酸 (17) はオキソ力 一ボンの一種であって特に安定である。

フェニルシクロブタジェノキノン（15）は，八ロゲン

表 7 非局在化エネルギー $(\mathrm{HMO})(\beta)^{27 b)}$

\begin{tabular}{c|c|c}
\hline & $\mathrm{X}=\mathrm{CH}_{2}$ & $\mathrm{X}=\mathrm{O}$ \\
\hline $\mathrm{X}=-=\mathrm{X}$ & 0.47 & 0.20 \\
$\mathrm{X}=-=-\mathrm{X}$ & 0.99 & 0.89 \\
\hline$=\mathrm{x}$ & 0.96 & 1.36 \\
\hline$=\mathrm{x}$ & 1.42 & 1.99 \\
\hline$=\mathrm{x}$ & & \\
\hline & & \\
\hline
\end{tabular}

と付加せず置換体 (15a) を与え，その他次ページの反応 式で示した通り種々の芳香族的置換反忘を起こす ${ }^{27,32 b) 。 ~}$ かつフェニルシクロブタジェノキノンのオキシ誘導体 (15c) はカルボン酸ビニログ $\left(\mathrm{p} K_{\mathrm{a}}=6.37\right)^{27 \mathrm{~b})}$ ， メトキ シ誘導体 (15d) はエステル，クロロ誘導体 (15a) は酸 クロリド，アミノ誘導体 (15b) はアミドである。シク ロブタジエノキノンのカルボニルは単なるケトンと異な るからケトン試薬と異常な反応も起こす。たとえば フェニレンジアミンと反応すると正規のキノキザリンを 与えず，(19a，b，c）を生じる。

シクロブタジエン(12)と同様にベンゾシクロブタジエ ン(20) (次ページ) も不安定で反応中間体としてだけ存在 が認められ,鉄カルボニル錯体(20a) は安定に合成された。

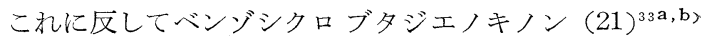
は安定で, $100^{\circ} \mathrm{C}, 0.2 \mathrm{mmHg}$ で分解せずに昇華し, 正 常のキノキザリン (22) を与える。光反応で各種の二量 体 $(23 \mathrm{~b}+23 \mathrm{~b} \rightarrow 24 \mathrm{a}, \mathrm{b} ; 23 \mathrm{a}+23 \mathrm{a} \rightarrow 24 \mathrm{c}, 23 \mathrm{a}+23 \mathrm{~b} \rightarrow 24 \mathrm{~d})$. を与える ${ }^{34)}$ 。無水マレイン酸, ジフェニルアセチレンの 共存下に (21) の光反応を行ならと, それぞれ中閒体 (23a，23b) に対応する生成物（25）(26）がえられる。 ベンゾシクロブタジエノキノンはブタジエノキノン誘導 体といらよりは，むしろベンゼンの側鎖に歪みのかかっ

注 シクロブテンジオン類の合成反応

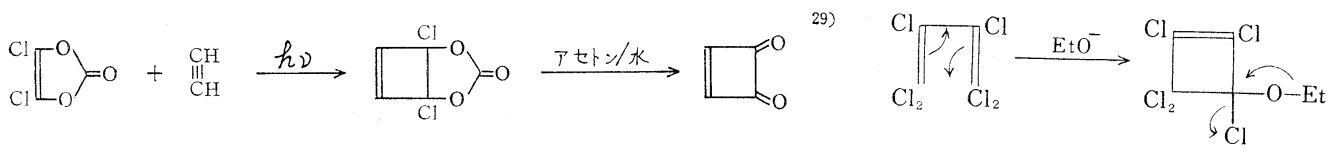

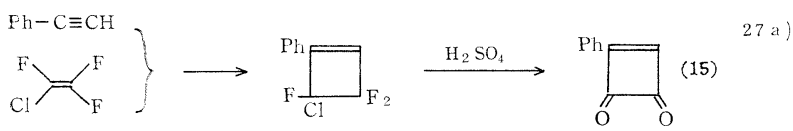

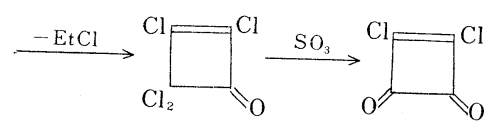

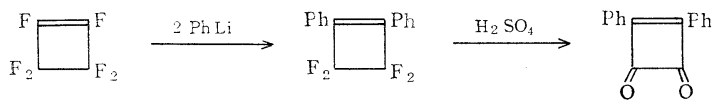

$30,31)$

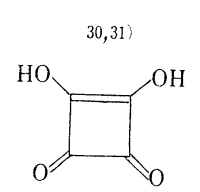

(17)

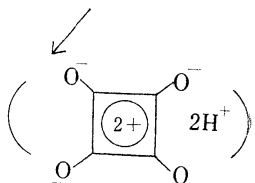



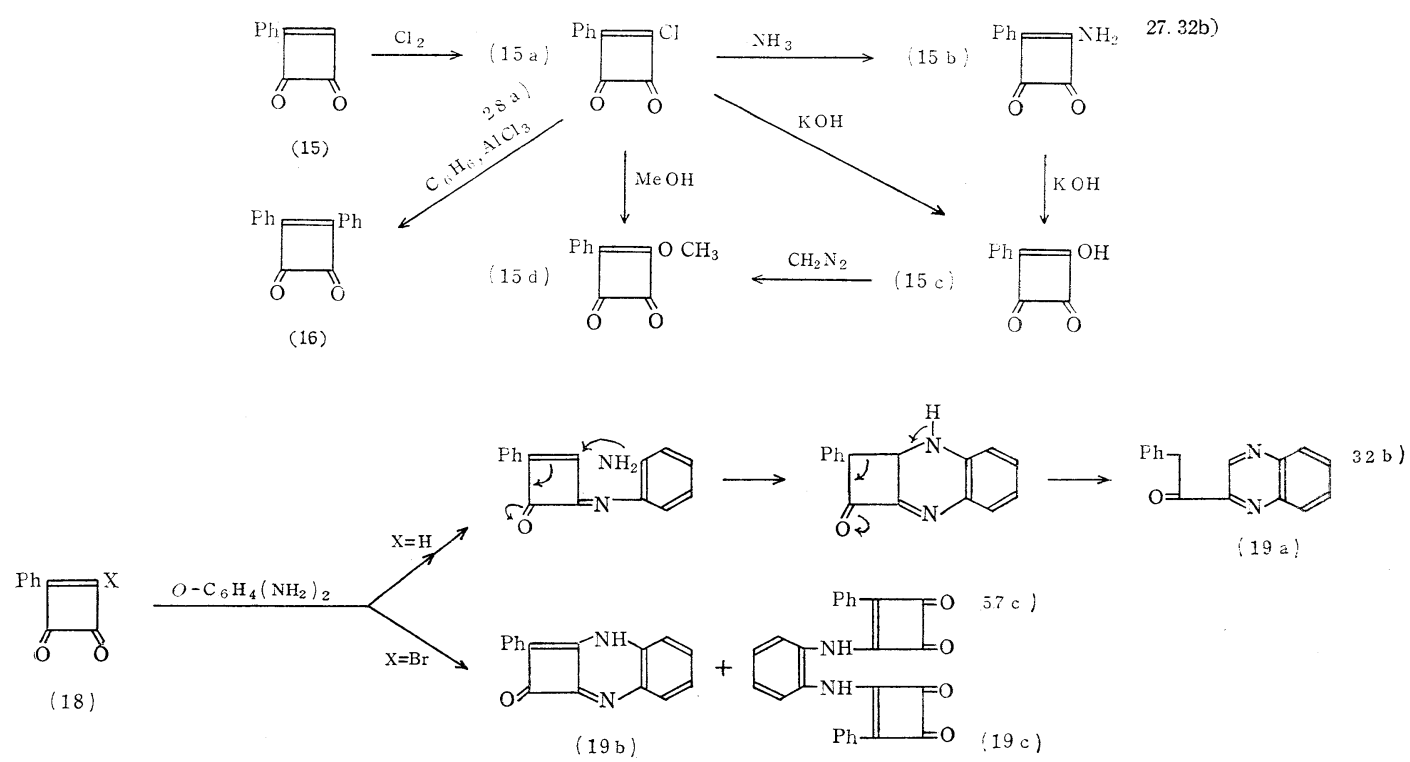

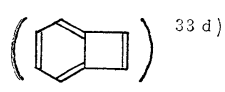

(20)
$\mathrm{Z}_{\mathrm{Fe}}(\mathrm{CO})_{3}{ }^{25}$

(20 a)
$\mathrm{P}_{\mathrm{I}}^{\mathrm{I}} \stackrel{2 \mathrm{AgNO}}{\longrightarrow} \mathrm{ONO}_{\mathrm{ONO}}^{\mathrm{ONO}_{2}} \frac{\mathrm{Et}_{3} \mathrm{~N}}{\mathrm{H}_{2} \mathrm{O}}$

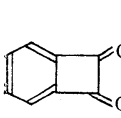

(21)

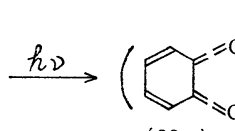

(23a)

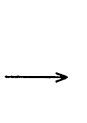<smiles>O=C1O[C]c2ccccc21</smiles>

(23b)
(21)

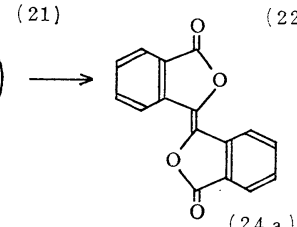

$\prod_{N}^{N}$

(22)

34)<smiles>O=C1OC(=C2OC(=O)c3ccccc32)c2ccccc21</smiles><smiles>O=C1OC2(C(=O)c3ccccc3C2=O)c2ccccc21</smiles>

(24d)

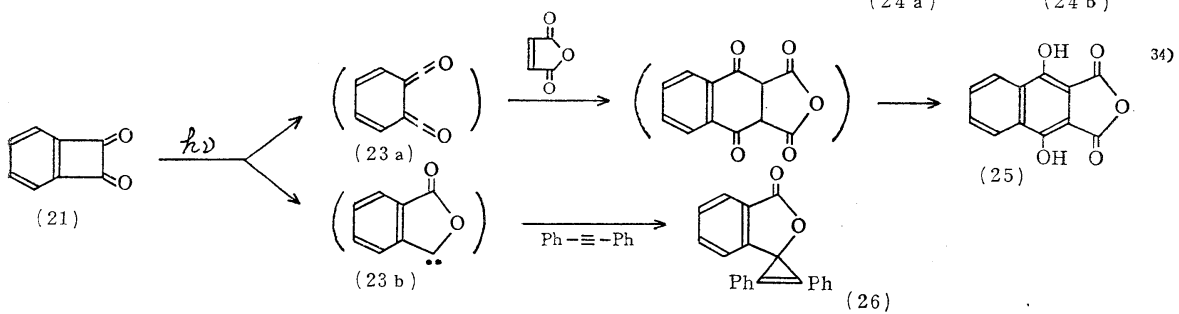

た ๙ージケトンがある化合物と見なす方が妥当である。

\section{III. シクロペンタジェノン}

1. シクロペンタジエノンの構造 シクロペンタジ エン (27) に相当するアニオン (27a) は $6 \pi$ 電子系芳 香族的構造，カチオン (27b) は $4 \pi$ 電子系反芳香族的 構造をもつ。したがってシクロペンタジェンはプロトン を放出してアニオンになる傾向があり, 酸性 $\left(\mathrm{p} K_{\mathrm{a}}=16\right.$,
表 12) を示し金属塩を与えるが，一方においてハロゲ ン化シクロペンタジエン誘導体 $(28,29)$ はハライドイ オンを放出すると不安定なカチオン (27b) 型になるの で，きわめてイオン化しにくい。たとえば 9-クロロ-9フェニルフルオレン (29) のイオン化解離定数は塩化卜 リフェニルメタン (3a) の 1/10,000 であり，(29）とト リフェニルメチルカチオン (3) からフェニルフルオレ ニルカチオン (29a) と（3a）ができる平衡はいちぢる 
しく左に片寄っている ${ }^{\text {bb) }}$ 。フベン（30）に扔いてもを の極性構造のうち $6 \pi$ 構造 $\left(30^{\prime}\right)$ の方が $4 \pi$ 構造 $\left(30^{\prime \prime}\right)$ より安定であるから 双極子モーメント (1.2 D, 実測值)

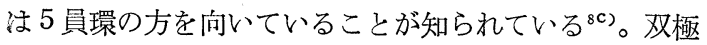
イオン $\left(30^{\prime}\right)$ 型化合物であるジアジシクロペンタジェン (31), シクロペンタジエノンヒドラゾン (32), シクロペ ンタジエニリド $(33,34)$ は安定で，(31) は種々の芳香 族的置換反応をする ${ }^{35)}$ 。一方潜在的仅双極イオン $\left(30^{\prime \prime}\right)$ 型化合物であるシクロペンタジエノン (35) は不安定で 単量体は得られず二量体 (36) だけが知られていた ${ }^{36 b)}$ 。 またシクロペンテンジオン（37）はエノル化としないこ 上が知られている ${ }^{36 a)}$
2 個以上のフェニル基と大きなアルキル基をもつ四置 換シクロペンタジエノンは安定であるが7a), それ以外 はすべて単量体は不安定でとり出せなく, 二量体として だけ存在する（表 8)。ことにテトラサイクロン (38) は 古くから知られていて安定で, $350^{\circ} \mathrm{C}$ まで変化しないが, 一方ジェン反応を起こしやすいので不安定中間体 (ベン ザインなど）を捕捉するのに使われている。その後モ $ノ-t-\mathrm{Bu}$ 置換体 $(39 \mathrm{a}, \mathrm{b})$ が液体窒素の温度 $\left(-196^{\circ} \mathrm{C}\right)$ で単離され, $シ ゙-t-\mathrm{Bu}$ 置換体 $(40 \mathrm{a}, \mathrm{b}, \mathrm{c})$ は室温で単離 され (ただし徐々に二量化), トリ- $t-\mathrm{Bu}$ 置換体 $(41 \mathrm{a}, \mathrm{b})$ は室温で十分安定 (二量化しない)なことがわかっ $た^{38,39)}$ 。さらに最近 $o$-ベンゾキノン，o-フェニレンカ

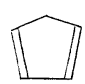

(27)

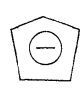

(27a)

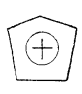

(27b)

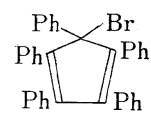

(28)

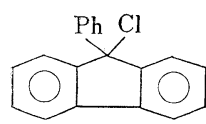

(29)<smiles>C#CC(c1ccccc1)c1ccccc1</smiles>

(3)

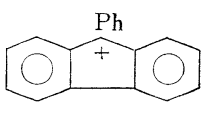

(29a)

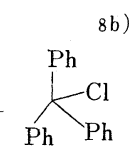

(3a)

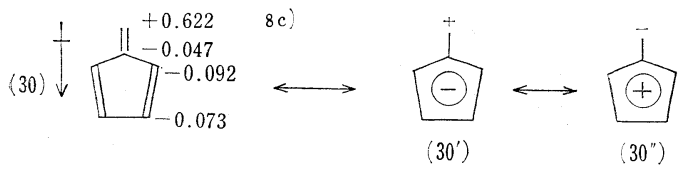

8)

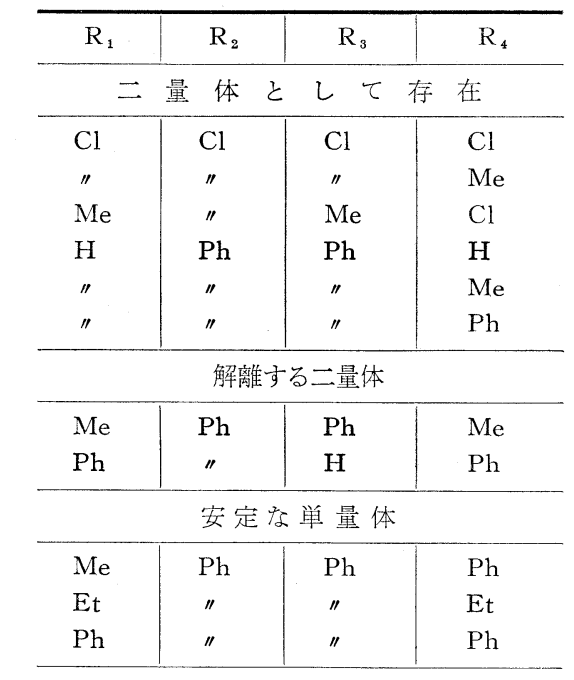

ルボナートまたは イトの熱分解で母体シクロペンタジェノン （35）を発生し, 液体窒素の温度で塩化ナト リウム板上に単離して IR が測定された。
(33)<smiles>C[Pb](C)c1ccccc1</smiles>

(34)
表 8 等 体 $^{37 a}$ )

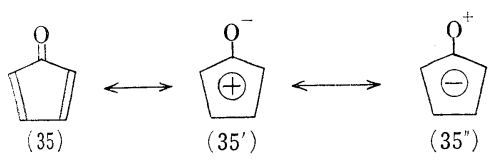


注 シクロペンタジェンン類の合成反応
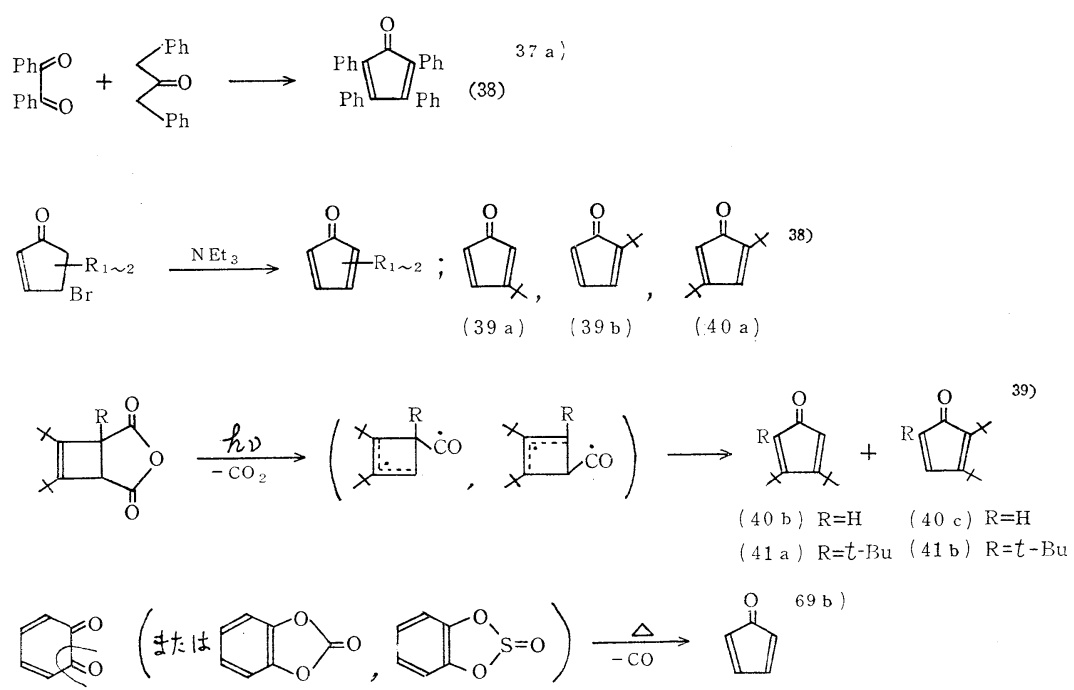

(35)

シクロペンタジエノン類の NMR はビニルプロトン が異常に高磁場にでる。これは 5 員環部の電子密度が高 いことを示している。その理由は次の通り。表9から, シクロペンテンがシクロペンタジェン（27）になるとビ ニルプロトンの 值が $0.82 \mathrm{ppm}$ 低くなる。このことを

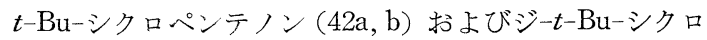
ペンタジエノン (40a) に適用すると $(40 \mathrm{a})$ では $\alpha-\mathrm{H}$ $3.35 \tau, \beta-\mathrm{H} 1.96 \tau$ (予想值) となる。実測值は表 9 の 通りで予想值より約 $1.5 \mathrm{ppm}$ 高い。この異常性は (40a) の $4 \pi$ 系常磁性環電流のためか, それとも環の電子密度 が高いためである。t-Bu-シクロペンテンと $t$ - $\mathrm{Bu}-$ ベン
ゼンの $t-\mathrm{Bu}$ の值を較べると後者の方がベンゼン核の 反磁性環電流のために $0.29 \mathrm{ppm}$ 低磁場シフトしている ことがわかる。一方 (42a，b，40a) の $t$-Bu の $\tau$ 值はほ ぼ等しい。故に $(40 \mathrm{a})$ には著しい環電流がないといえ る。とすると (40a) のビニルプロトンの異常性は $\left(35^{\prime \prime}\right)$ の寄与によって環の電子密度が高いためと考えられるの である。ただしテトラサイクロン（38）の双極子モーメ ントは酸素の方を向いていることがわかっているので, $\left(35^{\prime}\right)$ の方が $\left(35^{\prime \prime}\right)$ よりもより多くシクロペンタジエ ノンの基底状態に寄与していると考えられる ${ }^{38)} 。$

$\mathrm{CNDO} / 2$ 法の計算（表 10）によるとジビニルケトン

表 9 不飽和の 5 員環, 5 員環ケトンの $\operatorname{NMR}(\tau)^{38 b}$

\begin{tabular}{|c|c|c|c|c|c|c|c|}
\hline & & (27) & $\prod_{(42 a)}^{O}$ & $\sum_{(42 b)}^{0}$ & $\prod_{(40 a)}^{O 11}$ & & \\
\hline $\begin{array}{l}\text { ビニルH } \\
t-\mathrm{Bu}\end{array}$ & $\begin{array}{r}4.40 \\
-\end{array}$ & $\begin{array}{r}3.58 \\
-\end{array}$ & $\begin{array}{l}4.17 \\
8.79\end{array}$ & $\begin{array}{l}2.78 \\
8.83\end{array}$ & $\begin{array}{rr}\alpha 5.07, & \beta 3.50 \\
8.83, & 8.82\end{array}$ & $8 . \overline{68}$ & $8 . \overline{97}$ \\
\hline
\end{tabular}

表 $10 \mathrm{CNDO} / 2$ 法による計算值 ${ }^{599}$

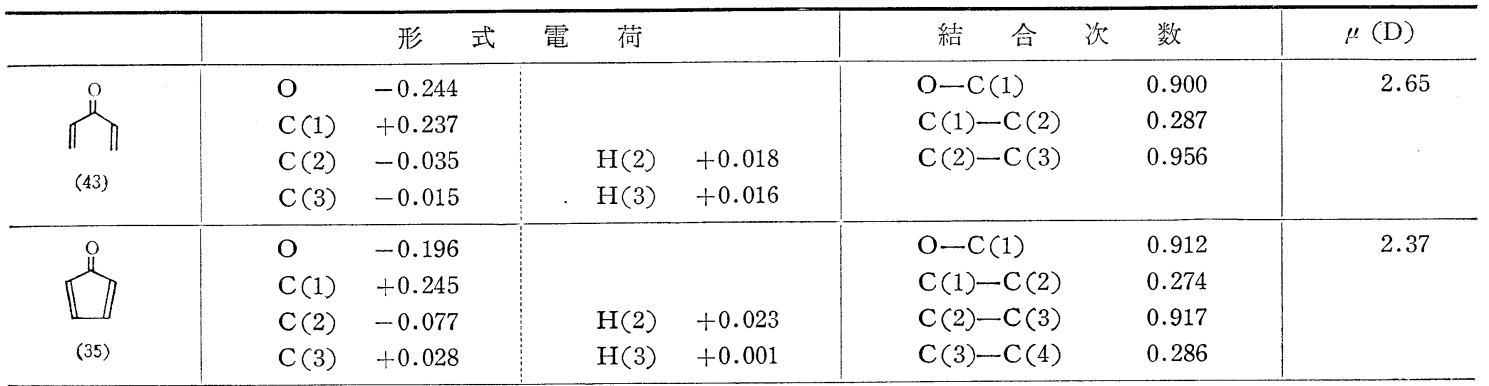


(35a)

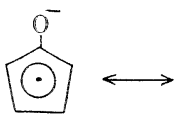

(35b)

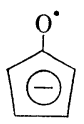

$\langle 77 \mathrm{a}$

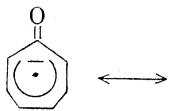

$(77 \mathrm{~b})$

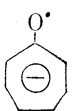

表 11 シクロペンタジェノンアニオンラジカルの $\mathrm{ESR}^{41)}$

\begin{tabular}{l|c|c|c}
\hline \multirow{2}{*}{ 位 } & \multirow{2}{*}{ 分離 定 数 } & \multicolumn{2}{|c}{ 不対電子密度 (計算) } \\
\cline { 3 - 4 } & & Hückel & McLachlan \\
\hline $\mathrm{C}(1)$ & - & 0.2355 & 0.2515 \\
$\mathrm{C}(2)$ & 2.91 & 0.1164 & 0.0905 \\
$\mathrm{C}(3)$ & 5.27 & 0.1770 & 0.2022 \\
$\mathrm{O}$ & - & 0.1779 & 0.1630 \\
\hline
\end{tabular}

（43）が環を結んでシクロペンタジエノン（35）になると 電子分布が環の方に移動し 双極子モーメントが少し小 さくなる。これはシクロペンタジエノンが双極イオン (35') の他に (35") の寄与をもつことを示している。 またシクロペンタジェノンのアニオンラジカルの ESR （表 11）とトロポン (77) のアニオンラジカルの ESR （表 23）を比較すると前者の $\sum a=16.4$ 後者の $\sum a=$ 27.6 となっている。これはシクロペンタジエノンアニ オンラジカルでは（35a）よりも（35b）の構造の寄与が 大きく, トロポンアニオンラジカルでは逆に (77a) の方 が (77b) よりも寄与が大きいことを示している。

2. シクロペンタジエノンのベンゾログシクロペ ンタジエン (27) に対するベンゼン核のアネレーション 効果は 表 12 に見られる。ベンゼン核が数多く縮環する ほど $\mathrm{p} K_{\mathrm{a}}, \mathrm{p} K_{\mathrm{R}^{+}}$共に大になる，すなわちシクロペンタ ジエニドアニオンの $6 \pi$ 電子芳香族的特徴が順次減少す るし，またシクロペンタジエニルカチオンの反芳香族性 も順次減少して安定になる。同様にしてシクロペンタジ エノン類もベンゼンが縮環するとシクロペンタジエノン 特有の反芳香族性が失われて正常のケトンに近くなる。

インドン (インデノン) (44) は安定であって単離で き(二量化もする)，シクロペンタジェノンのベンゾロ グであると同時にベンゼンの単なるエノン誘導体でもあ る。前出のシクロペンテンジオン（37）と異なりインダ ン-1,3-ジオン (46) はエノル化して酸性を示しアルカ リ溶液はアゾカップリングをする (下記反応式)。シク ロペンタジエノンが Diels-Alder 反応のジエンとして反 応するのに対してインドン (44) はジエノフィルとして 反応する。インドンのシクロペンタジエノンベンゾログ としての性質は表 13 に見られる。インドン (44) とイン ダノンの NMR を較べると, 前者の方がベンゼン核プ
ロトンの $\tau$ 值が高い。これはインドンの 5 員環部がシク ロペンタジエノン同様の常磁性環電流をもつかまた注電 子密度が高い（前述）ためである。またシクロペンテン とインデンのビニルプロトンを較べると $\alpha-\mathrm{H}, \beta-\mathrm{H}$ と もに後者の $\tau$ 值が低い。ところがシクロペンテノンとイ ンドンを較べると $\alpha-\mathrm{H}, \beta-\mathrm{H}$ ともに後者の $\tau$ 值が高い。 したがってインドンの 5 員環部はシクロペンタジエノン の特性を保持していることがわかる（すなわち双極イオ ン $\left(35^{\prime}\right)$ 型の主たる寄与の他に $\left(35^{\prime \prime}\right)$ 型の寄与が若干 ある)。フルオレノン (45) には最早シクロペンタジエノ ンの性質はない（2量化も Diels-Alder 付加もしない)。

表 12 シクロペンタジエン類の $\mathrm{p} K_{\mathrm{a}}$ と $\mathrm{p} K_{\mathrm{R}^{+}}$

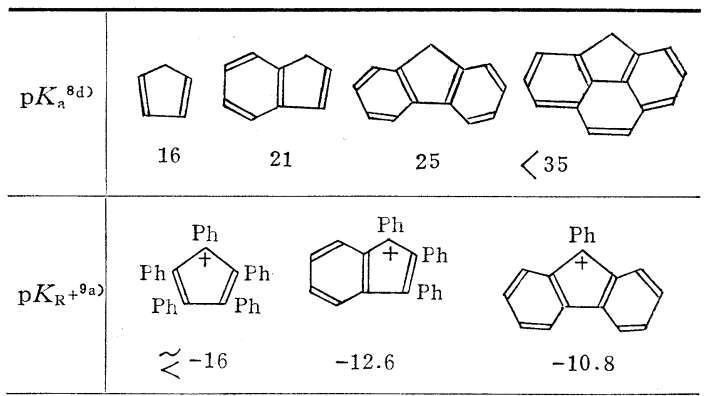

表 13 シクロペンテン，インデンおよびその対応ケト ン類の $\operatorname{NMR}(\tau)^{42)}$

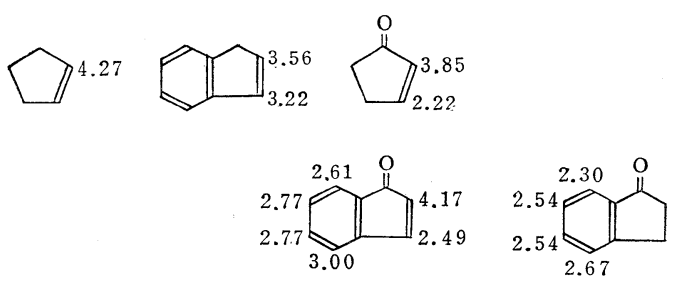

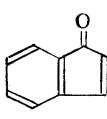

(44)

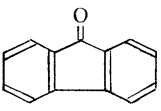

(45)

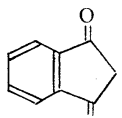

(46) $\mathrm{O}$<smiles>C#CC#[N+]C[C@H]1C=C(O)c2ccccc21</smiles>

インドンの異性体であるイソインデノン（47a）はま だ知られていない。1,3-ジフェニルイソインデノン （47b）は 2 量体 (47e) として得られ，単量体は反応中 間体としてのみ存在が確かめられた。2 量体 (47e) の生 成は外見上 $\left({ }_{\pi} 4_{\mathrm{s}}+{ }_{\pi} 4_{\mathrm{s}}\right)$ 環 状付加に見えるが，それは対 称禁制 (Woodward-Hoffmann 則) であるから，イソ インデン型 $\left(47 \mathrm{~b},{ }_{\pi} 4\right.$ 成分) とオキシアリル型 $\left(47 \mathrm{c},{ }_{\pi} 2\right.$ 成分）の間の $\left({ }_{\pi} 4_{\mathrm{s}}+{ }_{\pi} 2_{\mathrm{s}}\right)$ 環状付加であるかまたはジラ 
ジカル (47d) を至る 2 段階反応である ${ }^{43}$ 。 2 量体 (47e)＼cjkstart発生源である。すなわ 2 量体 $(47 \mathrm{e})$ とジエノフィルを一 は加熱すると容易に解離するから単量体 (47b) のよい 緒に加熱すると単量体 (47b) とジエノフィルの付加体

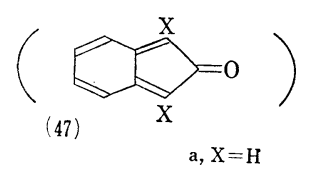

Ph

$(52 b)$

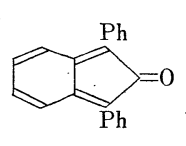

(47c)

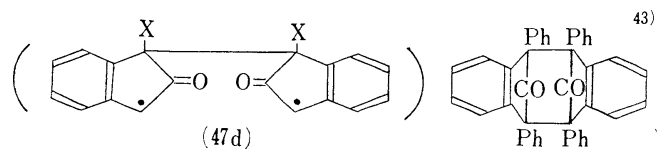

(47e)
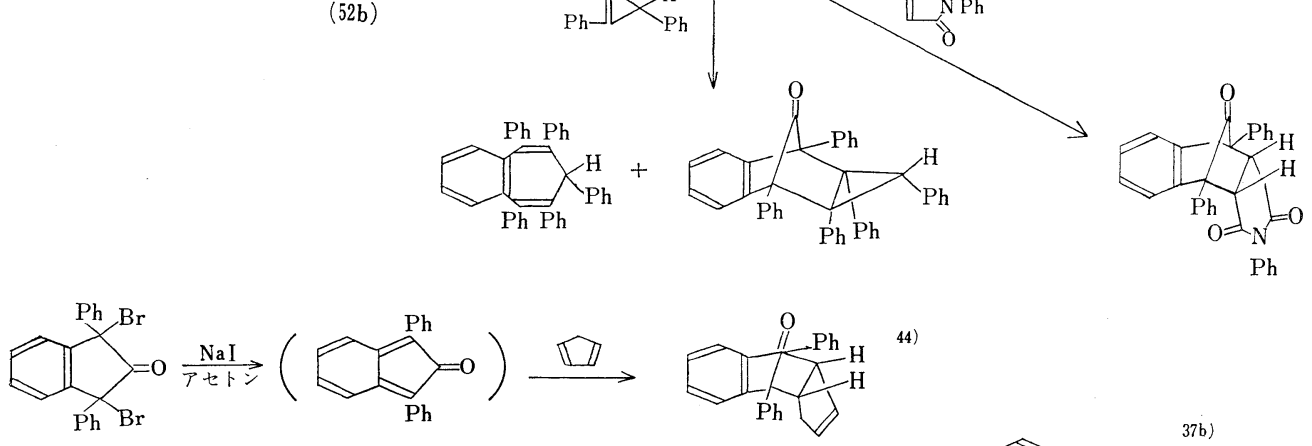

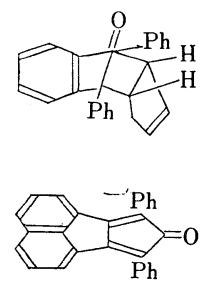

(48)

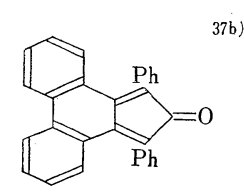

(49)

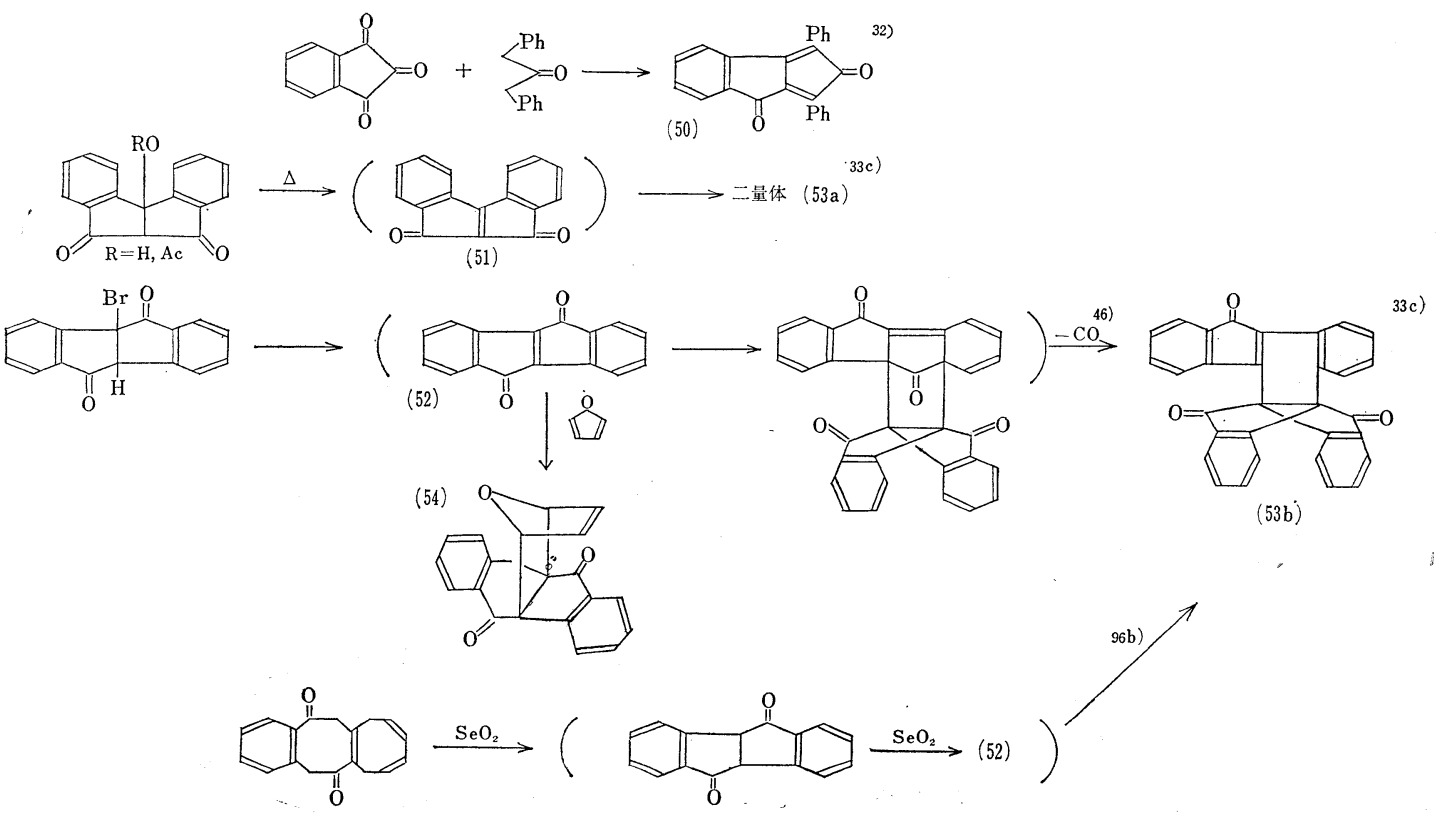


がえられる ${ }^{43)}$ 。(47a) の類似体でありそれぞれアセナフ テンキノン，フェナントラキノンの骨核をもっアセサイ クロン (48)，フェンサイクロン (49) は安定で古くから 知られていて, 前記テトラサイクロン (38) と同様に不 安定中間体の捕捉に利用される。

ベンゾペンタレノキノンを得る試みが二三報告されて いる。インダノサイクロン(50) (ベンゾペンタレノキ) ンの一種) は合成された ${ }^{32}$ 。 ジベンゾペンタレノキノン (51，52）を得る試夕は二量体 (53a), 四量体誘導体 (53b) を与えた。(中間に（52）を生じることは（54）の 生成によって確かめられた。)

2 つの反芳香族環（ $4 \mathrm{n} \pi$ 系）が縮環すると新しい芳香 族環 $(4 \mathrm{n}+2) \pi$ 系 ができると期待される ${ }^{9 \mathrm{e})}$ 。たとえ ば周辺 $10 \pi$ 系の 2,3 -シクロオクタテトラエノ-4-メチル シクロペンタジエノン (54) である。(54) ${ }^{9 \mathrm{f})}$ はクロロホ ルム溶液として得られ(溶媒を除去すると重合する), ビニルプロトンの化学シフトは $\delta 5.50 〜 6.50$ でシクロ オクタテトラエンと同じであり, 芳香族的安定性は認め られなかった。ただし塩基性が強く $\mathrm{p} K_{\mathrm{a}}=-2.3$ でシク ロプロペノン類（表 2）に匹敵する。シクロペンタジエ
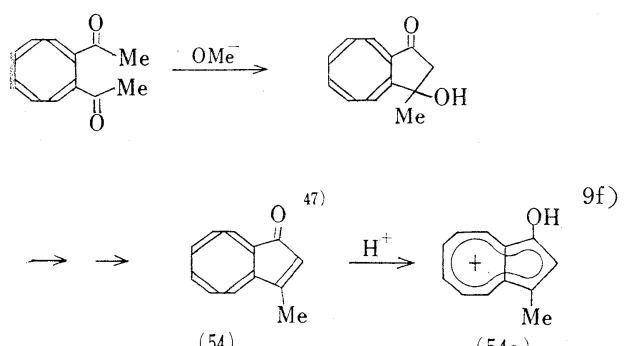

ノン誘導体でフェナレノンに関係ある化合物と ルて (72), (73) がある (995ページ)。

\section{IV. フェナレノン ${ }^{48}$}

六員環状の共役不飽和ケトンとしてベンゾキ ノン類がよく知られているが，ここではフェナ レノン類についてだけ述べる。フェナレン(ペ リナフテン) (55) から水素 1 個を取り除いたフ ェナレニル(ペリナフテニル）（55a）は奇交互炭 化水素で 1 個の NBMO があり，カチオン， ラ ジカル，アニオンはこの NBMO にそれぞれ $0,1,2$ 個の電子を入れているから 3 者とも等しい $D E=$ $5.83 \beta(\beta=20 \mathrm{kcal})$ を持つ $(\mathrm{LCAO}-\mathrm{MO})^{48,49}$ 。この值 はかなり大きいので，(55) が電子吸引基をもつ場 合は カチオンとして, 電子供与基をもつ場合はアニオンとし て安定化しうる。

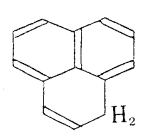

(55)

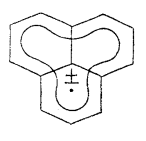

(55a)

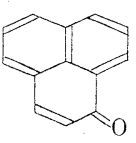

(56)

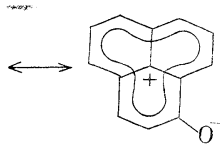

$\left(56^{\prime}\right)$
フェナレノン (ペリナフテノン) (56) は㓤辺 $12 \pi$ 共 役系 $\left(56^{\prime}\right)$ で岗るにもかかわらず上記の理由により芳香 族的安定性を示す。IR $\nu_{\mathrm{C}=\mathrm{O}} 1637 \mathrm{~cm}^{-1}$ と低く, 双極子モ 一メントは $3.89 \mathrm{D}$ と大きく塩基性も強い $\left(\mathrm{p} K_{\mathrm{b}}=0.4\right)$ 。 濃塩酸，60\% 硫酸に塩（56a）を形成して溶け水でうす めると回収する。フェナレノンのカルボニルと 2,3-二 重結合は単なるエノンの性質を示さない。たとえばフェ ナレノンは親ジエン体と付加反応しない。グリニャール 試薬と 1,4-付加して (57) になり, 蒸留すると脱水素し て9-フェニルフェナレノンになる。3-オキシフェナレ ノンはフェニルヒドラジンと反応して正規のヒドラン゙ン とならずに 2-アミノ体 (58) とアニリンになるなどであ る。また2-ブロモフェナレノン (59) はアミンと反応し て2-アミノ体 (60a) (正常置換) と 3-アミノ体 (60b) （異常置換）の両方を生じる。これらの性質は後述のト ロポンに類似し，フェナレノンの $\pi$ 電子が 3 つの環に非 局在化していることを示している。また表 14 の通り フェナレノンは芳香族的反磁性環電流が認められる。

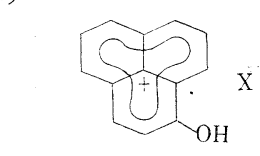

(56a)

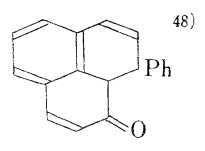

(57)

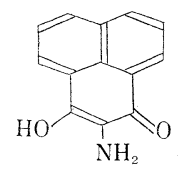

58

48) (59)

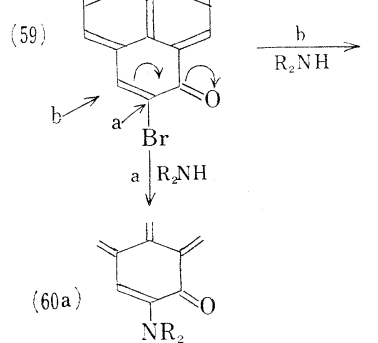

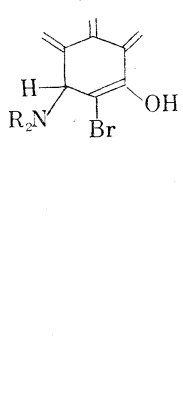

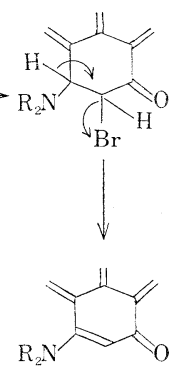

$(60 \mathrm{~b})$

村田ら ${ }^{50)}$ は数種のフェナレノン類似体を合成しその性

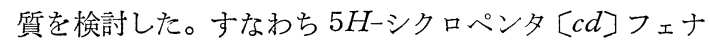
レン-5-オン (62) と 7H-シクロヘプタ [cd]フェナレ ンー7-オン (65) を合成し，その NMR 検討した結果, （62）は $12 \pi$ 周辺共役の〔13】アヌレノン $\left(62^{\prime}\right)$ であ 
り，(65）は $14 \pi$ 周辺共役の〔15〕アヌレノン $\left(65^{\prime}\right)$ で ともに内部のビニル基による摂動をうけた構造をもつこ とがわかった。その理由は次の通り。表 14 に示した通 りジヒドロ体 (61) に較べて（62）はフェナレン部が 0.48〜0.19 ppm だけ高磁場シフトし，テトラヒドロ体 （64）に較べて（65）のフェナレン部は最大 $0.32 \mathrm{ppm}$ ま で低磁場シフトしている。また（62）の NMR は重クロ ロホルム中でもトリフルオロ酢酸中でも大差ない（ $A=$ $0.29 \sim-0.27)$ が，それは $12 \pi$ 周辺共役による高磁場 シフトと陽電荷による反遮蔽効果が打ち消し合って重ク ロロホルム中の值とほぼ等しくなるのである。(65)の NMR はフェナレノン (56) の場合と同じく, 重クロロ ホルム中に較ベてトリフルオロ酢酸中では明瞭に低磁場 シフト $(\Delta=1.2 \sim 2.2 \mathrm{ppm})$ している。それは芳香族的 $14 \pi$ 周辺共役系の反磁性環電流のためである。(65) の構 造は中性で $\left(65^{\prime}\right)$, 酸性でそれにプロトン化したもので あることも考えられるが，もしそらなら結合定数が構造 の部分によって異なるはずであるが，実際は表 15 の通 り大体平均しているから，(65”）の構造はとっていない といえる。(65) の七員環部プロトンの $\delta$ 值は $12 \pi$ 周辺 共役のアセプレイアジェン $(67)$ ( $\delta 5.05,5.73)$ より きく, $14 \pi$ 周辺共役のアセプレイアジレン $(68)$ ( $\delta 6.79$, $6.85 \mathrm{ppm}$ ) に近い。これも（65）における反磁性環電流 のためである。また（67）の 7 員環部のジエンは無水マ
レイン酸と付加するが（65）は付加しない。なお（62） の $\delta$ 值はフェナレノン (56), 類似体 (65)よりも高磁場 で（62）が反芳香族であることを示している。最近 (62) と同様にその異性体 (63) も常磁性的であること，およ び（65）の異性体（66） 淍辺共役系ではなくエノン鎖 をもつフェナントレンの性質を示すことが報告された。 (56) の異性体である $6 H$-ベンズ〔cd]アズレン-6-オ ン (70a), 8H-ベンズ〔cd]アズレン-8-オン (70b) は 強酸に溶けてフェナレニウム型，たとえば $\left(70^{\prime}\right)$ にな る。3H-ベンズ〔cd]アズレン-3-オン誘導体 (71) は合 成されたが性質は検討されていない。(65) の異性体 $2 H$-ベンズ〔cd〕アズレン-2-オン (72) はまた知られ ていない。そのベンゾログ (73) は IR $\nu_{\mathrm{C}=\mathrm{O}} 1685 \mathrm{~cm}^{-1}$ で酸にとけ水でうすめると回収されるなど，フェナレノ ン (56) に類する性質がある。7H-ナフト $[3,2,1-c d]$ アズレン-7-オン (74) は中性溶媒中で NMR, UV を 見るとアズレン構造をもつが，強酸中ではアズレニウム 型ではなくフェナレニウム型である。1H-シクロへキサ [4,5,6-de]メタノ [10]アヌレン-1-オン (75) は橋か. けフェナレノン構造 $\left(75^{\prime \prime}\right)$ が期待されるがその性質は. なく,エノン鎖をもつ1,6-メタノ[10]アヌレン構造 $\left(75^{\prime}\right)$ であることがわかっている。6 員環共役不飽和ケトンと して他に (111〜115) がある(1004ページ)。上記の種々 のフェナレノン類似体をその製法と共に以下にあげる。
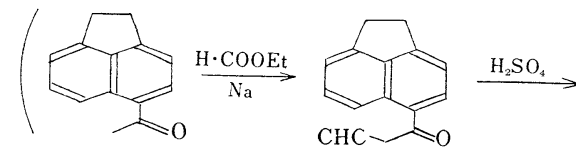

(6)<smiles>O=C1C=Cc2ccc3c4c(ccc1c24)CC3</smiles>
DD
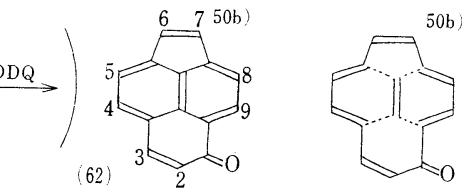

(62')

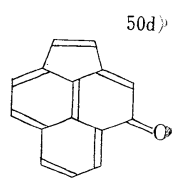

(63)
(64)<smiles>O=C1C=Cc2ccc3c4c(ccc1c24)CCC3</smiles>

(67)<smiles></smiles>

(65)

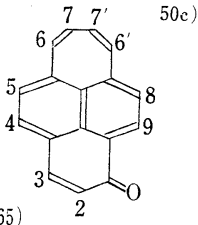

(68)

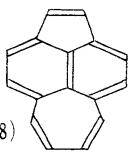

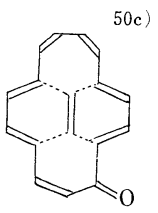

$\left(65^{\prime}\right)$

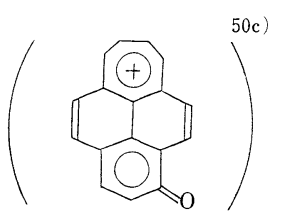

$\left(65^{\prime \prime}\right)$<smiles>O=C1C=CC2=CC=Cc3cccc4ccc2c1c34</smiles>

$66)$

$85 d$ 
表 14 フェナレノンおよび類似体の $\left.\operatorname{NMR}(\delta \mathrm{ppm})^{50 \mathrm{~b}, \mathrm{c}}\right)$

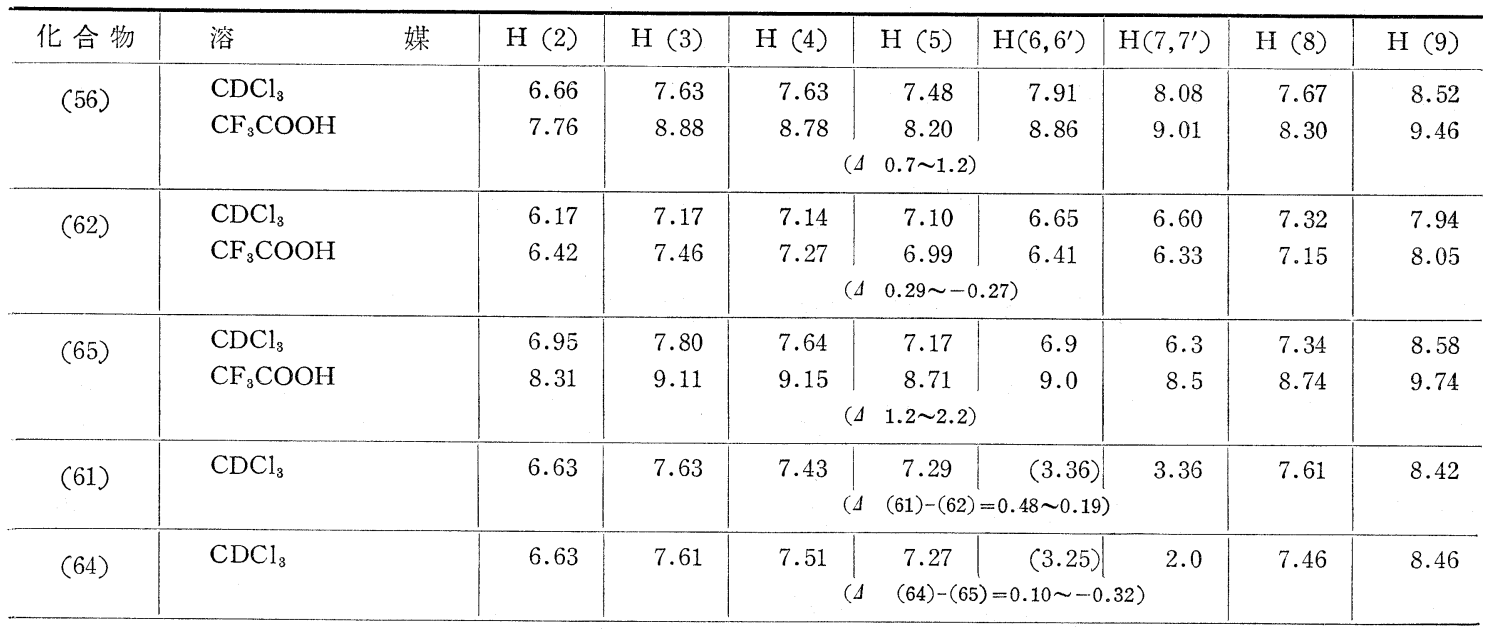

表 $15^{50} \mathrm{c}$ ) フェナレノン類似体 (65) の NMR 結合 定数 $(\mathrm{Hz})$

\begin{tabular}{l|c|c|c}
\hline 溶 媒 & $\mathrm{J}_{2,3}$ & $\mathrm{~J}_{4,5}$ & $\mathrm{~J}_{8,9}$ \\
\hline $\mathrm{CDCl}_{3}$ & 9.2 & 7.9 & 8.2 \\
$\mathrm{CF}_{3} \mathrm{COOH}$ & 8.7 & 8.4 & 8.9 \\
\hline
\end{tabular}
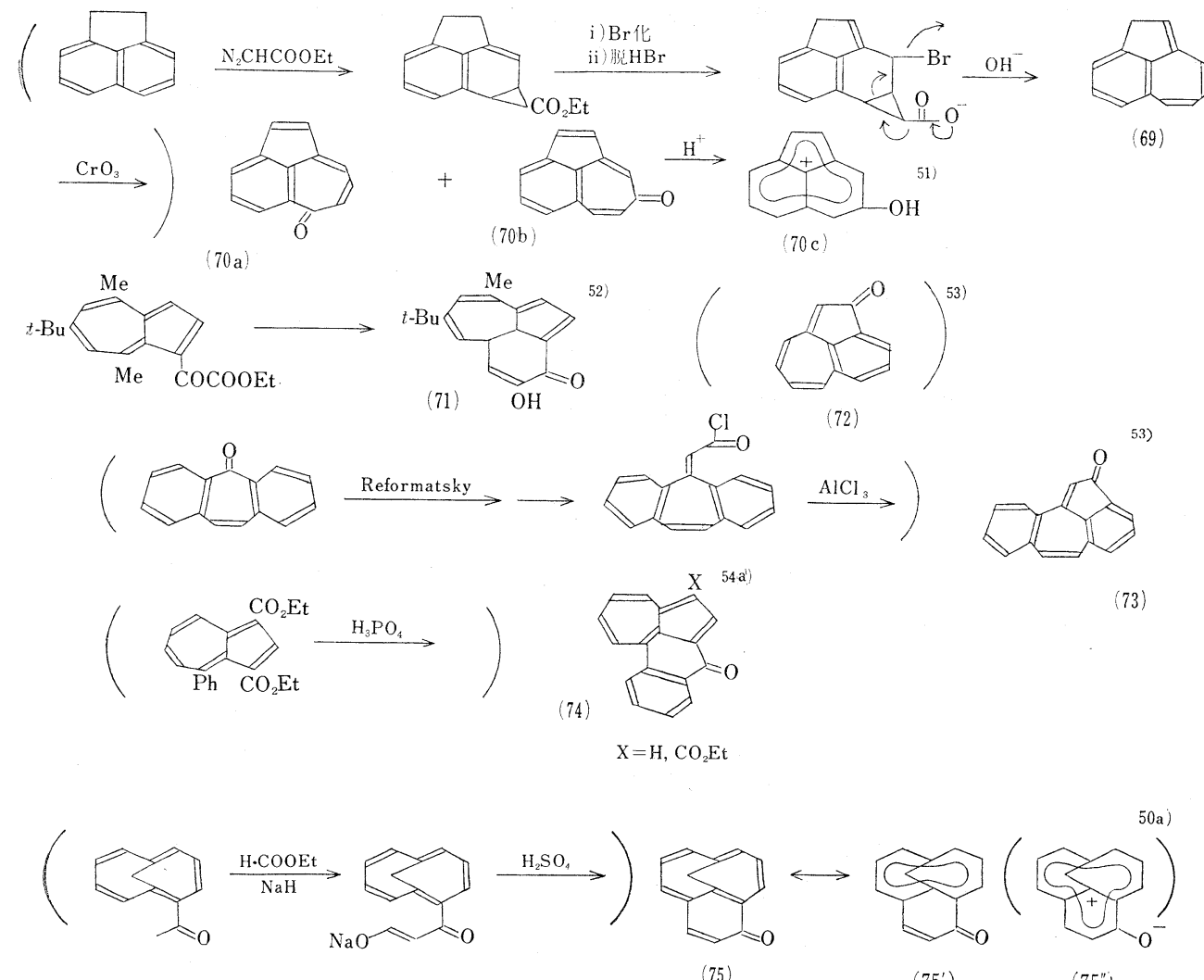

$$
\text { (75) }\left(75^{\prime}\right) \quad\left(75^{\prime \prime}\right)
$$




\section{V. トロポノイド5}

1.トロポンとトロポロントロピリウムカチオン （76）は典型的な非ベンゼン系芳香族化合物であり，IR， ラマン, NMR, UV, X線解析などから平面正 7 角形芳 香族構造が証明されている。トロポン（77）はトロピリ ウムカチオン類似の芳香族的双極イオン構造 $\left(77^{\prime}\right)$ の寄 与をもつと教えられる化合物である。卜ロポンは双極子 モーメントと塩基性が異常に大きくカルボニルの赤外吸 収は低波数部にあり（表 16），かつある種の芳香族的化 学反応を示すので $\left(77^{\prime}\right)$ の寄与が大きいと考えられてい

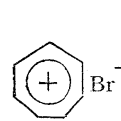

(76)

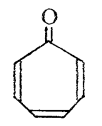

(77)

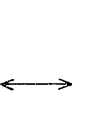

$\left(77^{\prime}\right)$
た。しかしその後の研究の結果, トロポンの芳香族性は 必ずしも大きくないことがわかってきた。

磁化率のエギザルテーションはベンゼン，アズレンな どの芳香族では炭素 1 原子当り 3.0 (単位 $-10^{6}$ ) 以上 あるのに，トロポンは 1.0〜1.8 で，トロピリデンと同 程度な゙ある（表 17）。共鳴エネルギーもトロポンはトロ ピリデン，ヘプタフルベンと同程度である（表 18）。電 子線扝よびX線回折研究によるとトロポンはトロピリデ ンに類する結合交替が見られる（図 2)。ただしトロポ ンおよび 2-クロロトロポン (78) は平面構造でありトロ ピリデンは折れ曲った構造（表 21）である。トロポン の HMO 計算も結合交替があることを示している（表 19)。 $\mathrm{CNDO} / 2$ 計算も同様である（衣 20）。すなわちト ロポンが平面で結合の長さが正規のポリエノン（単結合 1.52 ，二重結合 $1.34 \AA ̊$ ) であるとして双極子モーメント 在計算すると $\mu=3.88 \mathrm{D}$ の值がえられ，これは実测值 $4.30 \mathrm{D}$ に近い。もしトロポンが結合の長さ $1.41 \AA$ ( ベ ンゼンの值) の正七角形とすると $\mu=5.49 \mathrm{D}$ の計算值 となり実測值に合わない(59b)。トロポロンメチルエーテ ル (80) についてもポリエノンとして計算すると $\mu$ $4.76 \mathrm{D}$ となり実測值 $4.72 \mathrm{D}$ と一致する ${ }^{59 \mathrm{~b}) 。 以 上 の こ ~}$ とからトロポンはポリエノンの性質が大きいと考えられ る。トロポンがポリエノンでありながら平面構造をとる 理由はヘプタフルベンの歪みエネルギー（7 kcal）より もトロポンの平面ポリエノン構造の $D E$ の方が大きい

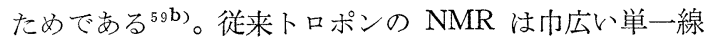
しかえられなかったが, 最近 $220 \mathrm{MHz}$ で解析が行なわ れた。それによると，NMR の結合定数 (形式単結合部 分の）からもトロポンの平面性（表 21）および結 合交

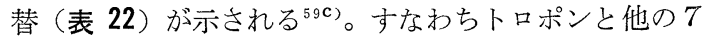
員環化合物の形式単結合の NMR 結合定数（表 21 の $\mathrm{J}_{3,4}$ ) を較べるとトロポンの值が大きくて平面性が高い ことを示しているし，トロポンの各結 合の NMR 結合 定数の差（表 22 の $\Delta=\mathrm{J}_{2,3}-\mathrm{J}_{3,4}$ ）をフェノールの場合 と較べるとトロポンでは差が大きく結合交替がいちぢる しいことがわかる。トロポン類のX線, 電子線解析の結 果を図 2 に示した。トロポン $\left(-60^{\circ} \mathrm{C}\right)$ は 2 種の結晶

(図 2 の $\mathrm{a}, \mathrm{a}^{\prime}$ ) があり結合交替がいちぢるしく，かつ ほとんど平面構造である。2-クロロトロポン（図 2 の c）もほぼ平面構造で， 7 員環の平均平面からのずれは Cが $0.014, \mathrm{H}$ が $0.21, \mathrm{O}$ が $0.07 \AA, \mathrm{Cl}$ は平面内に ある。また $\mathrm{C}(1)-\mathrm{C}(2)$ の距離は一般の $\mathrm{C}_{\boldsymbol{s} p^{2}}-\mathrm{C}_{\boldsymbol{s} p^{2}}$ $1.48 \sim 1.50 \AA$ に近いからこの結合は $\pi$ 電子の非局在化 に関係ない。すなおち 図 2 (e) の構造をとっている。 トリカルボニルトロポンクロミウム（図 2 の b $b^{\prime}$ ) も 同じく (e) の構造をとっている。かつこの場 合は平面 からのずれが大きい。なおトロポンを DMF 中電解還元 して生じるアニオンラジカルの ESR 測定は McLachlan

表 16 スベロン, トロポンの物理定数の比較 ${ }^{55 a, c)}$

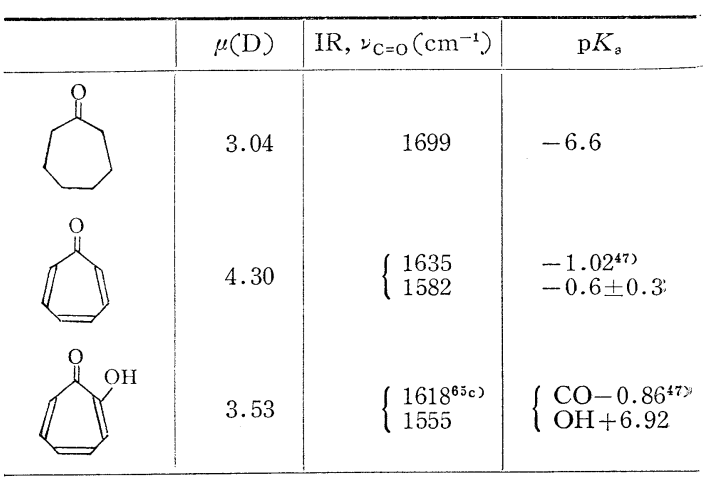

表 1756a) トロポンおよび類似体の磁化率 $\left(-10^{6} x\right)$

\begin{tabular}{l|c|c|c}
\hline 実 測 值 & Pascal & $\Delta / \mathrm{C}$ \\
\hline & 55.6 & 36.9 & 3.1 \\
\hline & 91.0 & 55.7 & 3.5 \\
\hline
\end{tabular}


法計算值とよく一致する実測值を与え, 不対電子が 7 員 環の方に主として分布している構造 (77a) を示してい る（表 23）(シクロペンタジエノンアニオンラジカル (35b) と対照的)。トロポンの ${ }^{13} \mathrm{C}-\mathrm{NMR}$ の濃度依存性 が調べられた（図 3)。四塩化炭素中ではトロポンの濃 度が減少するにつれて ${ }^{13} \mathrm{C}$ のケミカルシフトは, C (1), $\mathrm{C}(2,7), \mathrm{C}(4,5)$ :高磁場シフトし, $\mathrm{C}(3,6)$ は低磁場 シフトする。酢酸中では逆に, 濃度が減少すると C(1),

表 1856) トロポンおよび類似体の共鳴エネルギー $(\mathrm{Kcal} / \mathrm{mol})$ (水素化熱力ら）(*燃燒熱か、ら）

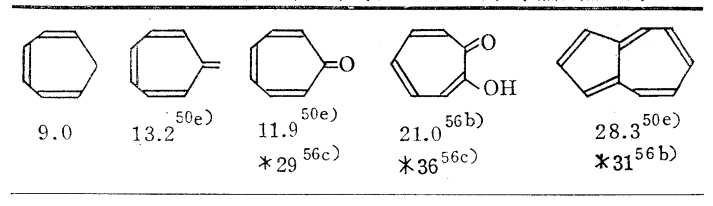

表 19 トロポンの電子密度と $\pi$ 結合次数 $(\mathrm{HMO} \text { 法 })^{58>}$

\begin{tabular}{|c|c|c|c|c|c|}
\hline & $\begin{array}{l}\nu_{\mathrm{C}=0} \\
\mathrm{~cm}^{-1}\end{array}$ & 電子焉 & 密度 & $\pi$ 結合次数 & \begin{tabular}{|l|l} 
NMR, \\
ミカルシ \\
フト $(\tau)$
\end{tabular} \\
\hline & 1582 & $\begin{array}{ll}\mathrm{O} & 1 \\
\mathrm{C}(1) & 0 \\
\mathrm{C}(2) & 0 \\
\mathrm{C}(3) & 0 \\
\mathrm{C}(4) & 0\end{array}$ & $\begin{array}{l}1.735 \\
0.830 \\
0.926 \\
0.889 \\
0.903\end{array}$ & $\mid \begin{array}{rr}\mathrm{O}-\mathrm{C}(1) & 0.534 \\
\mathrm{C}(1)-\mathrm{C}(2) & 0.540 \\
\mathrm{C}(2)-\mathrm{C}(3) & 0.705 \\
\mathrm{C}(3)-\mathrm{C}(4) & 0.599 \\
\mathrm{C}(4)-\mathrm{C}(5) & 0.688\end{array}$ & $\mathrm{H}(3) 3.05$ \\
\hline & 1590 & $\begin{array}{ll}\mathrm{O} & 1 \\
\mathrm{C}(1) & 0 \\
\mathrm{C}(2) & 0 \\
\mathrm{C}(3) & 0 \\
\mathrm{C}(4) & 0\end{array}$ & $\begin{array}{l}1.696 \\
0.804 \\
0.978 \\
0.865 \\
0.960\end{array}$ & $\begin{array}{rr}\mathrm{O}-\mathrm{C}(1) & 0.569 \\
\mathrm{C}(1)-\mathrm{C}(2) & 0.515 \\
\mathrm{C}(2)-\mathrm{C}(3) & 0.749 \\
\mathrm{C}(3)-\mathrm{C}(4) & 0.507 \\
\mathrm{C}(4)-\mathrm{C}(5) & 0.517\end{array}$ & $\begin{array}{ll}\mathrm{H}(2) & 3.35 \\
\mathrm{H}(3) & 2.73\end{array}$ \\
\hline
\end{tabular}

表 20 トロポンの双極子モーメント $(\mu)$, 形式電荷, $\pi$ 結 合次数 $\left(\mathrm{CNDO} / 2\right.$ 法 $^{59 \mathrm{~b}, 67)}$

\begin{tabular}{|c|c|c|c|c|c|c|c|}
\hline & $\mu$ & & 形 式 & 電 & 荷 & \multicolumn{2}{|c|}{$\pi$ 結合次数 } \\
\hline & $4.30 \mathrm{D}$ & $\mathrm{O}$ & -0.298 & & & $\mathrm{O}-\mathrm{C}(1)$ & 0.865 \\
\hline & & $\mathrm{C}(1)$ & +0.246 & & & $\mathrm{C}(1)-\mathrm{C}(2)$ & 0.324 \\
\hline & & $\mathrm{C}(2)$ & -0.038 & $\mathrm{H}(2)$ & +0.018 & $C(2)-C(3)$ & 0.883 \\
\hline & 3. & $\mathrm{C}(3)$ & +0.039 & $\mathrm{H}(3)$ & -0.005 & $\mathrm{C}(3)-\mathrm{C}(4)$ & 0.369 \\
\hline & （計算 & C (4) & +0.015 & $\mathrm{H}(4)$ & -0.002 & $C(4)-C(5)$ & 0.874 \\
\hline
\end{tabular}

表 21 トロポンおよび類似体の NMR 結合定数と平面性 ${ }^{61.59 \mathrm{c})}$
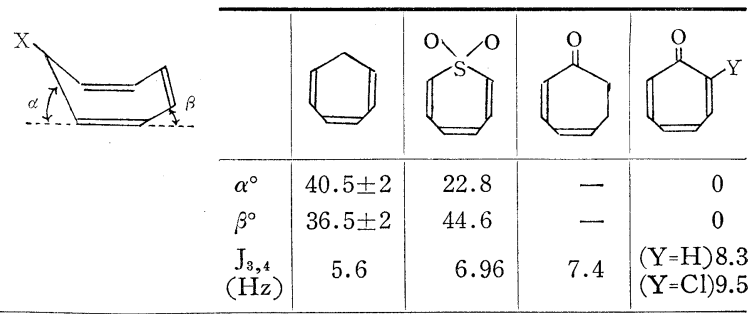

$\mathrm{C}(2,7), \mathrm{C}(4,5)$ は低磁場シフトし, $\mathrm{C}(3,6)$ は高磁場 シフトする。この相違はトロポンのカルボニルが酢酸と 水素結合して極性構造 $\left(77^{\prime}\right)$ の寄与が大きくなるためで ある。トロポンと臭素の反応は, 四塩化炭素中ではへキ サブロモ付加体を与え，酢酸中ではトリブロモ置換体を 与える。 ${ }^{13} \mathrm{C}-\mathrm{NMR}$ 測定の結果から，トロポンは酢酸中 では $\pi$ 電子の非局在化により安定化が増大するために置 換反応が起こるものと考えられる ${ }^{60 \mathrm{~d}) 。 ~}$

トロポロン (88) はトロポンに較べて $6 \pi$ 電子構造の 特徴が顕著である。それは分子内水素結合 $\left(79^{\prime}\right)$ をくく む互変異性によって強い安定化を受けるためである。卜 ロポンの計算值（表 19）とトロポンの計算（表 24） を較べると, 後者の方が結 合交替が少ない。X線回折

表 22 トロポンおよび類似体の NMR 結合定数の北較 ${ }^{59}$ c)

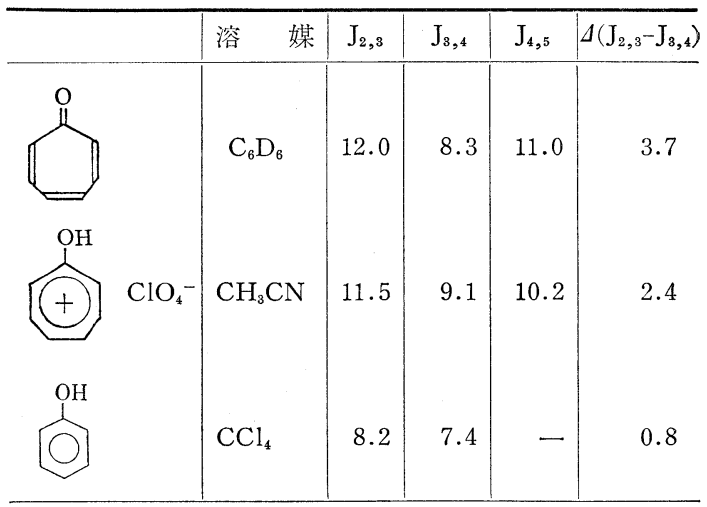

表 23 トロポンアニオンラジカルの $\mathrm{ESR}^{65 \mathrm{a}}$

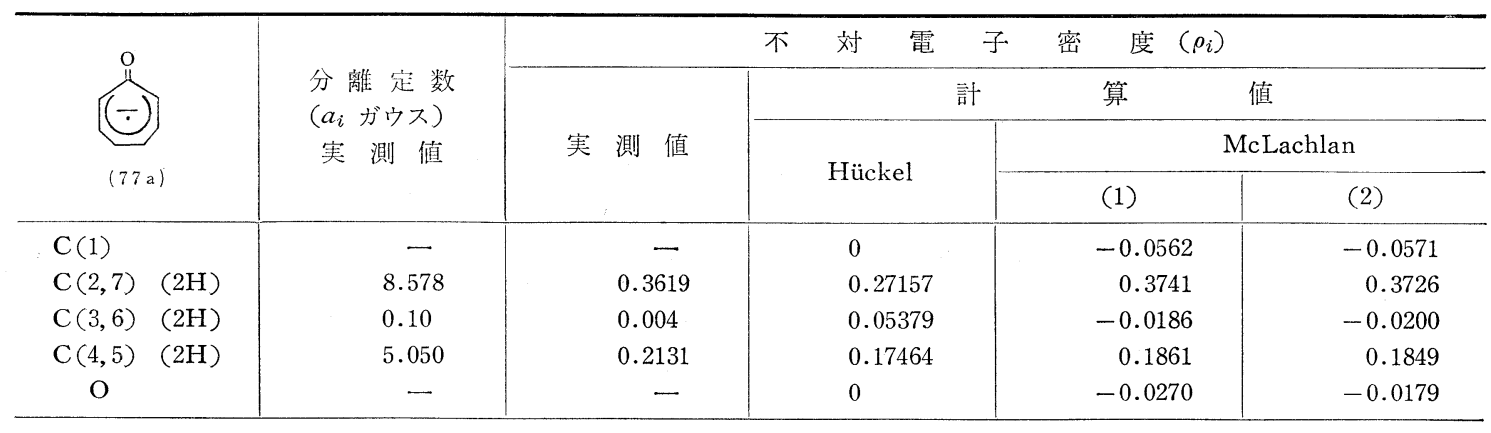


a)トロポン, $\mathrm{X}$ 線 $\left(-60^{\circ} \mathrm{C}\right)^{62 \mathrm{a})}$
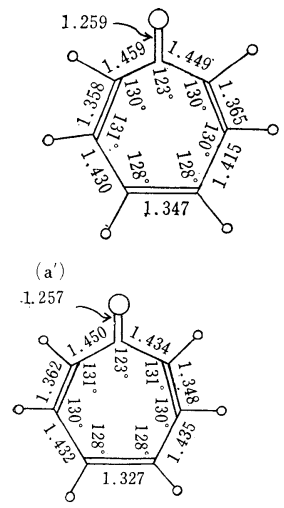

c) 2-クロロ下ロポン，

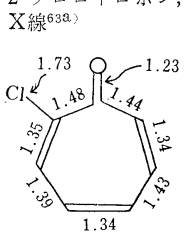

d) トロビリデン， 電子線 ${ }^{61)}$

e)

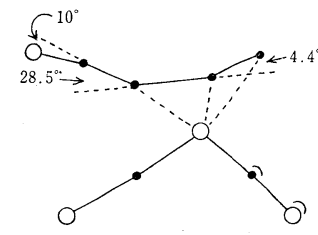

図 2 トロポン類 (およびトロピリデン)のX線, 電 子線解析図 (環外数字洁結合距離 $\AA$, 環内数字 柱結合角)
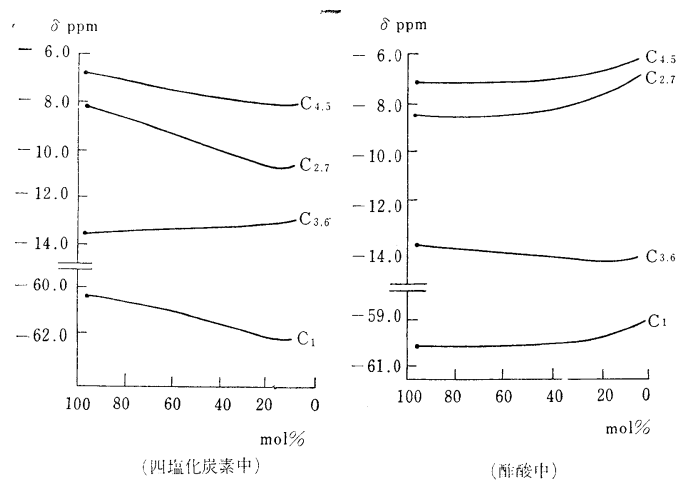

図 3 トロポンの ${ }^{13} \mathrm{C}-\mathrm{NMR}$ の濃度依存性 ${ }^{60}$ d) (ヘンゼン基準)

(図 4)によるとトロポロンは平面で結合交替が少なく炭 素炭素間距離の平均值は $1.407 \AA$ で芳香族化合物の平 均值 $1.392 \AA$ にきわめて近い66a)。トロポロンのカルボ ニルの塩基性（ $\mathrm{p} K_{\mathrm{a}}=-0.86 ）$ はトロポンのそれ $\left(\mathrm{p} K_{\mathrm{a}}\right.$ =-1.02）より強い（表 16）。トロポロンの共鳴エネル ギーは比較的大きい（表 18）。しかし磁化率（表 17） のエギザルテーションはあまり大きくない。ことに改良 Pascal 和とのずれはトロピリデンと同程度であって, ト ロポロンがポリエン的性質をもつことを示している ${ }^{59 \mathrm{C}) 。 ~}$<smiles>[R]C1(O)CC1([R])O</smiles>

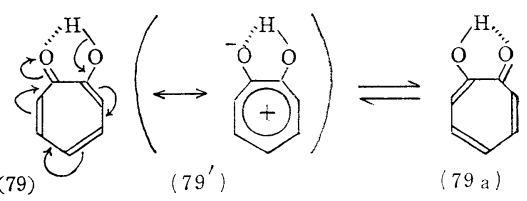

(80)

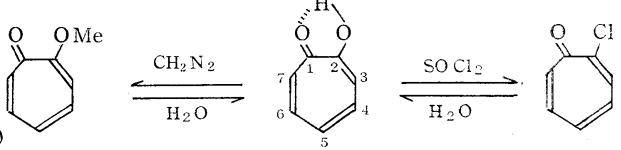

(81)<smiles></smiles>

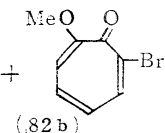

トロポロンはカルボン酸のビニログであり酸の強さ（表 16）は（酢酸 $\mathrm{p} K_{\mathrm{a}} 4.75 ）$ とフェノール（ $\mathrm{p} K_{\mathrm{a}} 9.95 ） の$ 中間である。トロポロンはカルボン酸と同様にケトン試 薬と反応せず，ジアゾメタンでメチルエーテル $(80)$, 塩 化チオニルで 2-クロロトロポン（78）になり，(80) と （78）はそれぞれエステル，酸クロリドの性質を示し， 加水分解してトロポロンに戻る。トロポロンは互変異性 混合物 $(79) \leftrightharpoons(79 a)$ として存在する。このことは, 3-ブロモトロポロン (81) をメチル化すると 2 種のメチ ルエーテル $(82 \mathrm{a}, \mathrm{b})$ になること, トロポロンの NMR が $\mathrm{AA}^{\prime} \mathrm{BB}^{\prime} \mathrm{C}$ 型であり,さらに $\mathrm{J}_{3,4}(10.9 \mathrm{~Hz})$ はトロポロ ンメチルエーテル $(80)$ の $\mathrm{J}_{3,4}(10.1 \mathrm{~Hz})$ と $\mathrm{J}_{6,7}(12.0 \mathrm{~Hz})$ の平均であること, トロポロンの $\mathrm{J}_{4,5}(9.9 \mathrm{~Hz})$ は (80) の $\mathrm{J}_{4,5}(11.0 \mathrm{~Hz})$ と $\mathrm{J}_{5,6}(8.4 \mathrm{~Hz})$ の平均であること（表 26), トロポロンの ${ }^{13} \mathrm{C}-\mathrm{NMR}$ 弾純な 4 本のシングレ ットであること（表 27, 帰属は $\pi$ 電子密度の計算值に 基ずく。すは最低磁場の吸収を基準とした相対値)などか ら示される。3-および 4-イソプロピルトロポロンのラ マンスペクトルにおける振動の帰属からこれらがそれぞ れ互変異性混合物であることが示された ${ }^{65 \mathrm{c}}$ 。またいわ ゆる 3-ブロモトロポロン (81) の NMR $\left(\mathrm{CDCl}_{3}\right)$ で $\mathrm{J}_{4,5}=10.2, \mathrm{~J}_{6,7}=10.6 \mathrm{~Hz}$ であるが, $\mathrm{J}_{5,6}=9.6 \mathrm{~Hz}$ と小さ いから3-ブロモ体 (81) と7-ブロモ体 (81a) の平衡は (81)の方に傾いていることがわかってくる（次ページの 式 $\left.^{70 \mathrm{~b})}\right)$ 。トロポロンは平面構造で結合交替が小さいが, 置換基がたくさんつくと様子が変ってくる。3,5,7-トリ ブロモヒノキチオール（83）のX線解析（図 5）による と 7 員環は結合交替を示し, 約 $1.35 \AA$ と $1.44 \AA$ の二 種の結合があり，環は舟型で $\mathrm{C}_{2} \mathrm{C}_{3} \mathrm{C}_{6} \mathrm{C}_{7}$ の面に対して $\mathrm{C}_{3} \mathrm{C}_{4} \mathrm{C}_{5} \mathrm{C}_{6}$ の面は $18.5^{\circ}$ 傾き, $\mathrm{C}_{1} \mathrm{C}_{2} \mathrm{C}_{7}$ の面は $17.3^{\circ}$ 傾い ている。5- $\mathrm{Br}, 6-i \mathrm{Pr}, 7-\mathrm{Br}$ の 3 者の反溌のために $\angle \mathrm{C}_{5}$ $\mathrm{C}_{6} \mathrm{C}_{7}$ は最も小さい。この化合物は通称 4-イソプロピル 
体であるが，結合交替からいらと（83a）または図 5 の 番号の通り 6-イソプロピル体といらことになる ${ }^{70 a)}$ 。 また別に（83a）のジケトン型（83b）が単離されてい る54b)。一般にトロポロ入類はいわゆるトロポロン型で 存在しジケトン型で単離されることは希である。トリブ ロモヒノキチオールの場合はトロポロン型 (83a) が平面 性を失っているのでジケトン型（83b）々較べて両者の

表 24 トロポロンの電子密度, 結合次数, 結合距離 ( $\mathrm{SCF}-\mathrm{MO}$ 計算) ${ }^{87)}$

\begin{tabular}{|c|c|c|c|}
\hline 電子密度 & & 結合次数 & $\begin{array}{l}\text { 結合距離 } \\
(\AA)\end{array}$ \\
\hline $\mathrm{O}(1) 1.5160$ & $\mathrm{O}(1)-\mathrm{C}(1)$ & 0.74618 & 1.276 \\
\hline $\mathrm{O}(2) 1.7901$ & $\mathrm{O}(2)-\mathrm{C}(2)$ & 0.46670 & 1.326 \\
\hline $\mathrm{C}(1) \quad 0.7719$ & $\mathrm{C}(1)-\mathrm{C}(2)$ & 0.35158 & 1.454 \\
\hline $\mathrm{C}(2) \quad 0.9259$ & $\mathrm{C}(2)-\mathrm{C}(3)$ & 0.70691 & 1.390 \\
\hline $\mathrm{C}(3) 1.0772$ & $\mathrm{C}(3)-\mathrm{C}(4)$ & 0.54374 & 1.419 \\
\hline$C(4) 0.9541$ & $\mathrm{C}(4)-\mathrm{C}(5)$ & 0.75370 & 1.381 \\
\hline $\mathrm{C}(5) 1.0230$ & $\mathrm{C}(5)-\mathrm{C}(6)$ & 0.52411 & 1.423 \\
\hline$C(6) \quad 0.9441$ & $\mathrm{C}(6)-\mathrm{C}(7)$ & 0.78470 & 1.376 \\
\hline $\mathrm{C}(7) \quad 0.9978$ & $C(7)-C(1)$ & 0.42933 & 1.440 \\
\hline
\end{tabular}

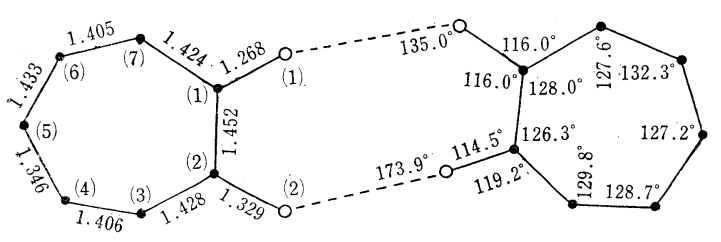

图 4 トロポロンのX線解析（在側数字注結合距離 $\mathrm{A}$, 右睤数字(小結合角 $)^{66 \mathrm{a})}$

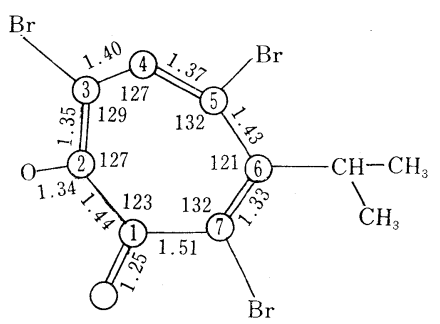

表 25 トロポロン類の ${ }^{5} K_{\mathrm{a}}{ }^{55 \mathrm{~b}, \mathrm{c})}$

\begin{tabular}{l|l|l}
\hline & $\mathrm{X}=\mathrm{H}$ & 6.92 \\
& $\mathrm{Me}$ & 7.92 \\
& $\mathrm{Br}$ & 5.92 \\
\hline & & 5.40 \\
\hline 3-オキシトロポン & & 5.65 \\
\hline
\end{tabular}

表 26 トロポソ類の NMR 結合定数 $(\mathrm{Hz})^{59 \mathrm{c}}$ )

\begin{tabular}{l|l|l|l|l}
\hline & $\mathrm{J}_{3,4}$ & $\mathrm{~J}_{4,5}$ & $\mathrm{~J}_{5,6}$ & $\mathrm{~J}_{6,7}$ \\
\hline
\end{tabular}

表 27 トロポロンの $\pi$ 電子密度 ${ }^{67)}$ と ${ }^{18} \mathrm{C}-\mathrm{NMR}^{68,60 \mathrm{~d})}$

\begin{tabular}{l|c|c}
\hline $\mathrm{C}$ 番号 & $\delta(\mathrm{ppm})$ & $\pi$ 電子密度 \\
\hline 1,2 & 0 & 0.8489 \\
4,6 & 34.6 & 0.9491 \\
5 & 44.0 & 1.0230 \\
3,7 & 48.2 & 1.0375 \\
\hline
\end{tabular}

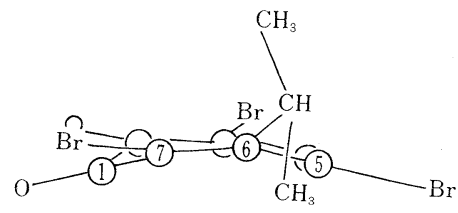

図 $53,5,7$-トリブロモヒノキチオールの $\mathrm{X}^{\text {線解析 }}{ }^{70 a}$ ) (環外数字結合距離 $\AA$, 環内数字結合角 ${ }^{\circ}$ )

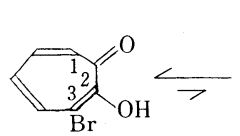

(81)<smiles></smiles>

(81a)
(83)<smiles>CC(C)c1c(Br)ccc(Br)c1Br</smiles>

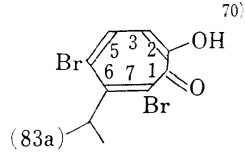

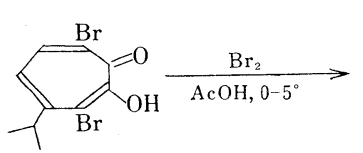

(84)<smiles>CC(C)C1=C(Br)CC(=O)C(=O)C1Br</smiles>

(85)<smiles></smiles>

(83b) 
安定性に大差がない。そのため両型がほぼ同程度に存在 し，両方とも単離されるのである。3,7-ジブロムヒノキ チオール (84) も平面性を失っていてポリエン構造をも つため臭素と付加して (85) を生じる。(これを加熱する と臭化水素を放出して (83) になる)。3-ニトロトロポロ ネートアニオンラジカルの ESR によると不対電子密度 の実測值はニトロ基がカルボニル基との立体障害のため に7員環と約 $40^{\circ}$ 傾いているとしての計算值とよく一致 することも知られている ${ }^{65 \mathrm{~b}) 。 ~}$

トロポノイドの詳細な化学反応は野副らの著書 ${ }^{55,56,57)}$ にゆずることにし，ここには比較的最近の研究である分 子内環化反応 ${ }^{69,71}$ について若干解説する。トロポンの最 高被占軌道己最低空軌道の符号から判断してノルカラジ エノン $(86,86 a)$ とビシクロ [3.2.0]ヘプタジエノン (87,87a） 一異性化するわけであるが，(86a)，(87a）は 歪みが大きいから除外すると, トロポンは熱反応でノル カラジェノン (86), 光反応ではビシクロヘプタジエノ ン（87）亿異性化することになる ${ }^{71 a)}$ 。(86) は確認され ていないが，トロポンを $500^{\circ} \mathrm{C}$ に加熱すると定量的にべ ンゼンと一酸化炭素に分解するから，途中に（86）を生 成すると考えられる ${ }^{71 b)}$ 。(87) は安定であり，たとえば (88)，(89）は $400^{\circ} \mathrm{C}$ 以上に加熱して初めてそれぞれメ トキシトロポン (80)，(91) に戻る。ビシクロ体 (87) が

（分子内環化湟よる異性化）

$(87 a)$
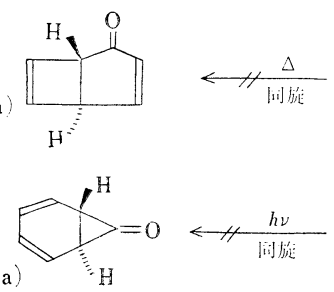
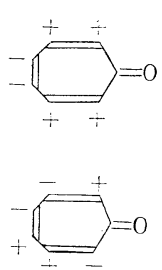

( LVMO)

(HOMO)
安定である理由は，これが熱的に同旋的開環すると歪み の大きいトランストロポン (77c) にならねばならないか らである。ただしトロポン自身は光照射すると分子内環 化ではなく二量化する。2-メトキシ (80) および 4-メト キシトロポン (92) は光照射で分子内環化し $\left.{ }^{69 e}, \mathrm{f}\right), 3-メ$ トキシトロポン (91) は分子内環化しない(69)。まず （80）の場合を説明する ${ }^{69 \mathrm{e})}$ 。(80) をメタノール中で光 照射するとビシク口体 (88)，（89）が生じ，水中光照射 した場合は（88），(90）が生成物となる。反応機構は, まず励起分子 (80a) が生じ（メトキシ基のためにそれの ついた炭素が励起されたものが安定化する)，それが分 子内環化して (88) となる。さらに二次的に (88) がビ

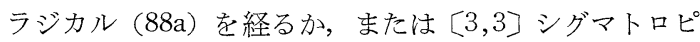
一移動でケテン (88b) を生成し, それから (89) に変 わる ${ }^{69 \mathrm{~d}, 72)}$ 。水中反応では (89) が (89a) を経て開環し て（90）になる。3-メトキシ体（91）に光照射すると励 起種 (91a) となる。これはもとに戻るだけであって分子 内環化できない。4-メトキシ体 (92) の光反応は励起種 (92a)を経て環化して (93) を与える。トロポロンも光 照射で同様に分子内環化する ${ }^{87)}$ 。な扔, 5 位にフェニル， シアノ，ホルミル，カルボキシルなどの電子吸引基をも つトロポロンに光照射して生じるビシクロヘプタジエノ ンは暗所で室温で容易にもとの 5-置換トロポロンに戻
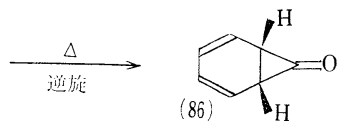

71b)
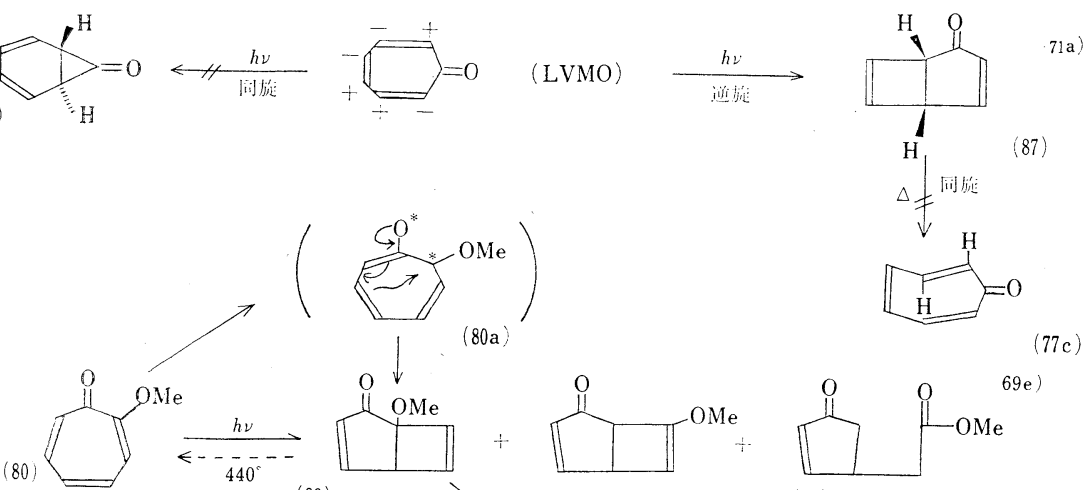

$(77 \mathrm{c})$

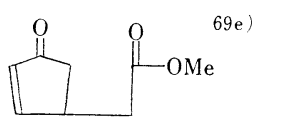

(90)

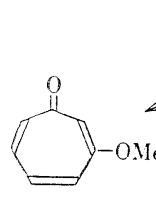

(91)

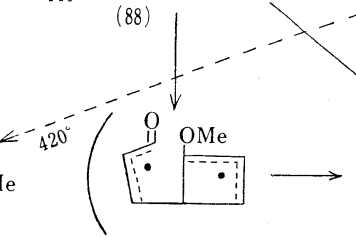

(88 a)

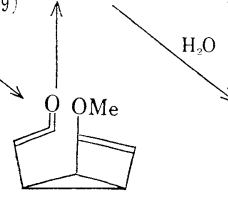

$(88 b)$

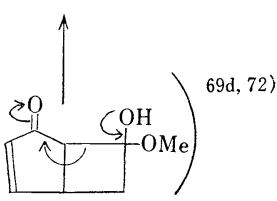

$89 a)$ 
<smiles></smiles>

(91)

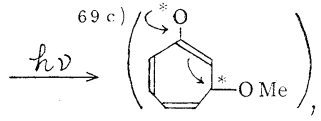

(91 a)

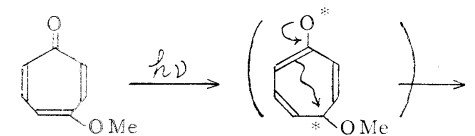

(92)
$(92$ a

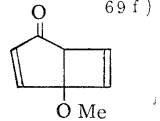

(93)
るといら特徴がある ${ }^{64 \mathrm{~b})}$ 。この開環反応は分子内環状脱 離反応ではなくイオン的な協奏反応と思われる。

2. トロポン, トロポロンのベンゾログ 正 7 角形 の $6 \pi$ 電子系芳香族構造をもつトロピリウムイオン (76) にベンゼンが縮環するとベンゼン環の数が多い程七員環 部の芳香族的安定性が失われることが表 28 亿示してあ る。これと同様にトロポノイドの場合もベンゼンアネレ ーションによってトロポノイドの特性が減少する傾向が ある。X線回折によると 5-クロロ-2,3-ベンゾトロポン （95）（表 29，図 6)，4,5-ベンゾトロポン (96）（図 7) の構造はほとんど平面（ごくわずかずれている）だが結

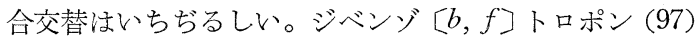
（図 8）注カルボニル酸素とペリ位の水素の立体的相互 作用のため七員環部は舟型となり，2つのベンゼン環は $39^{\circ}$ に傾いている。それ故最早トロポン謑導体ではなく 双極イオン構造 (97') の寄与はない。表 19 の HMO 計 算によると，トロポンと 4,5-ベンゾトロポン (96) を較 ベて，(96）の方が，酸素の電子密度が低く，カルボニル の結合次数が大きく, $\mathrm{C}(2)$ と $\mathrm{C}(3)$ の電子密度の差が 大きい。

これはトロポンの場合の双極イオン $\left(77^{\prime}\right)$ の寄与に較 ベてベンゾトロポンに対する双極イオン $\left(96^{\prime}\right)$ の寄与が 少ないことを示している。スベロンに較ベてトロポンの 塩基性は大きい（表 16 の $\mathrm{p} K_{\mathrm{a}}$ ）がジベンゾスベロンと ジベンゾトロポンの塩基性はほぼ等しい（表 30）。表 31 のトロポン類のカルボニルの赤外吸收と $\pi$ 結合次数はト ロポンとベンゾトロポンは大差ないが，ジおよびトリべ ンゾトロポンになるとベンゾフェノンにほぼ等しくな る。表 19 と表 31 を通して見て, トロポン, ベンゾト ロポン, ジベンゾトロポンの順にカルボニル酸素の電子 密度が減少している。これもこの順に双極イオン $\left(77^{\prime}\right)$ 型の寄与が少ないことを示している。表 32 のトリベン ゾ $[b, d, f]$ トロポン誘導体（98）のカルボニル基の赤 外吸収は， $\mathrm{R}_{2}$ に置換基があっても影響ないが， $\mathrm{R}_{1}, \mathrm{R}_{4}$ に置換基がありかつそれが大きいとカルボニル吸收が高 波数にずれるから七員環部がいちぢるしく舟型になるこ

とがわかる。一方ジインデノベンゾトロポン (99) はか ルボニル吸収が低波数を示すから，構造が 平面で $\pi$ 電 子非局在化がよいことがわかる。表 33 の NMR 結合定 数を見ると初めの 3 つの化合物，すなわち 7 -メチルー 1 , 2-ベンゾシクロヘプタトリエン，1,2-ベンゾヘプタフル ベン，2,3-ベンゾトロポンを較ベると形式二重結 合の $\mathrm{J}_{\mathrm{a}, \mathrm{b}}$ 抢よび $\mathrm{J}_{\mathrm{c}, \mathrm{d}}$ は 3 つの化合物についてほぼ同じであ るが，形式単結合 $\mathrm{J}_{\mathrm{b}, \mathrm{c}}$ は 3 つの化合物についてこの 順に大きくなる。このことは 3 つの化合物の $\pi$ 電子非局 在化はほぼ同程度であるが，形式単結合の二面体角がこ の順に小さくなる（平面性が大になる）ことを示してい る59a)。ベンゾトロピリウムイオンは平面性がもっとも 大きい。以上からわかるように，トロポン，トロポロン 環にベンゼンが縮環するとトロポノイドの特性が失われ る。なお表 34 のベンゾトロポンの架橋化合物 (101) は $\mathrm{n} \leq 6$ のとき $\nu_{\mathrm{CO}}>1650 \mathrm{~cm}^{-1}$ で非平面， $\mathrm{n} \geq 7$ のとき $\nu_{\mathrm{CO}}<1610 \mathrm{~cm}^{-1}$ で平面である。 $\mathrm{Ha}$ の NMR $(\delta)$ および 半波電位も同じ結論を与える。表 35 のビス架橋化合物 (102) では $\mathrm{n} \geqslant 4$ が平面構造である。2,7-ノナメチレン トロポン (100) は平面で IR $\nu_{\mathrm{C}=\mathrm{O}} 1624,1588 \mathrm{~cm}^{-1}$ で卜

\section{表 2873a) トロピリウムイオンの $\mathrm{p} K_{\mathrm{R}+}$}

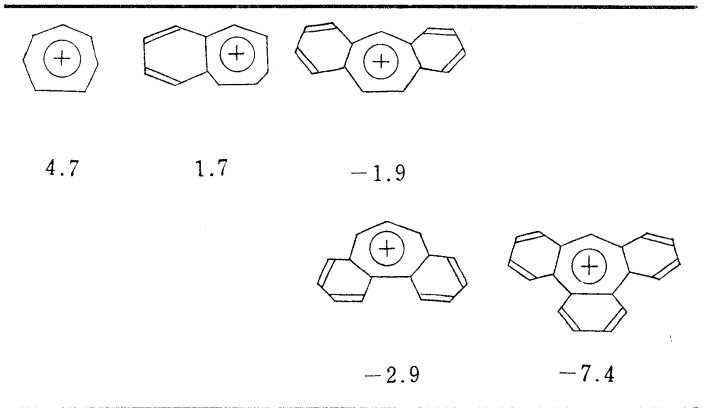

表 2966b) 5-クロロ-2,3-ペソゾトロポンの結合距離 (Å, X線)

\begin{tabular}{|c|c|c|}
\hline$(95)^{4}{ }^{5} \mathrm{Cl}$ & $\begin{array}{ll}\mathrm{O}-\mathrm{C}(1) & 1.254 \\
\mathrm{C}(1)-\mathrm{C}(2) & 1.490 \\
\mathrm{C}(2)-\mathrm{C}(3) & 1.391 \\
\mathrm{C}(3)-\mathrm{C}(4) & 1.468\end{array}$ & 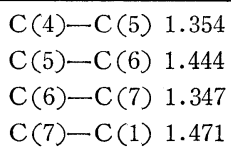 \\
\hline
\end{tabular}

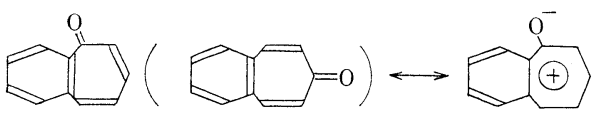

(94)

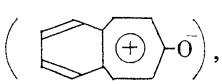

$\left(96^{\prime}\right)$
(96)

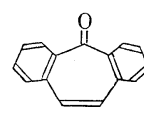

(97)
(94')

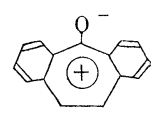

$\left(97^{\prime}\right)$ 


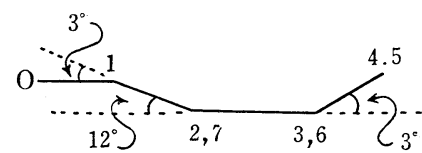

図 6 5-クロロ-2,3-ベンゾトロポソ $(\mathrm{X} \text { 線 })^{66 \mathrm{~b}}$

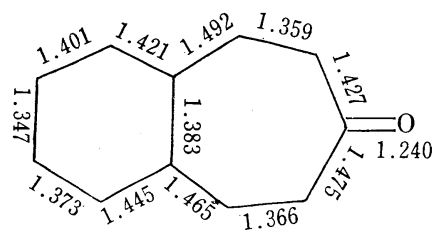

図 7 4,5-ベンゾトロポンの結合距離 $(\AA, \mathrm{X} \text { 線 })^{66 \mathrm{c}}$ )
表 32 トリベンゾトロポンのカルボニル基の赤外 吸収 $\left(\mathrm{cm}^{-1}\right)^{76)}$
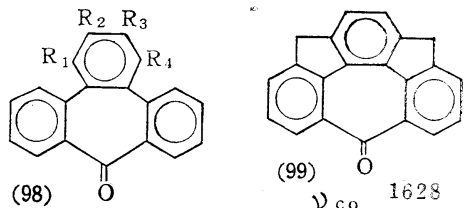

\begin{tabular}{c|c|c|c|c|c}
\hline (98) & $\mathrm{R}_{1}$ & $\mathrm{R}_{2}$ & $\mathrm{R}_{3}$ & $\mathrm{R}_{4}$ & $\nu_{\mathrm{C}=0}$ \\
\hline $\mathrm{H}$ & $\mathrm{H}$ & $\mathrm{H}$ & $\mathrm{H}$ & 1670 \\
& $\mathrm{CO}_{2} \mathrm{H}$ & $\prime \prime$ & $\prime \prime$ & $\prime \prime$ \\
$\mathrm{Me}$ & $\mathrm{H}$ & $\prime \prime$ & $\mathrm{Me}$ & 1690 \\
$\mathrm{Ph}$ & $\mathrm{Ph}$ & $\mathrm{Ph}$ & $\mathrm{Ph}$ & 1695 \\
\hline
\end{tabular}

表 33 ベンゾトロポンおよび類似体の NMR 結合定数 $\left.(\mathrm{Hz})^{59 a}\right)$

\begin{tabular}{|c|c|c|c|c|c|c|}
\hline & $d$ & & & & & o \\
\hline $\begin{array}{l}\mathrm{J}_{\mathrm{a}, \mathrm{b}} \\
\mathrm{J}_{\mathrm{b}, \mathrm{c}} \\
\mathrm{J}_{\mathrm{c}, \mathrm{d}}\end{array}$ & $\begin{array}{r}10.0 \\
5.5 \\
11.5\end{array}$ & $\begin{array}{r}11.5 \\
6.8 \\
11.5\end{array}$ & $\begin{array}{r}11.5 \\
8.3 \\
11.3\end{array}$ & $\begin{array}{r}12.8 \\
- \\
-\end{array}$ & $\begin{array}{r}10.2 \\
9.8 \\
9.8\end{array}$ & $\begin{array}{r}9.8 \\
11.9 \\
-\end{array}$ \\
\hline
\end{tabular}
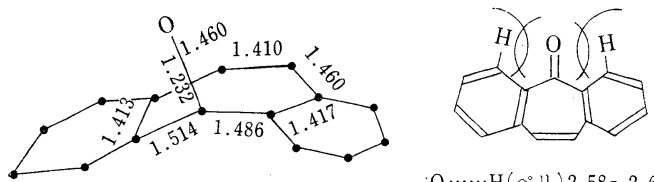

$\mathrm{O} \cdots \cdots \cdot \mathrm{H}($ ペリ) $2.58 \sim 2.63$

図 8 ジベンゾ $[b, f]$ トロポンの結合距離 $(\AA, \mathrm{X} \text { 線 })^{66 \mathrm{c}}$ )

表 30 ジベンゾスベロン, ジベンゾトロポンの $\mathrm{p} K_{\mathrm{a}}{ }^{74)}$

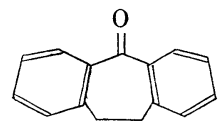

$-5.69$

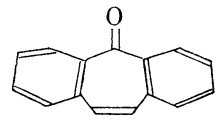

$-5.25$

表 $31 \mathbf{a}$ カルボニル酸素の電子密度 $(H M O)^{75}$
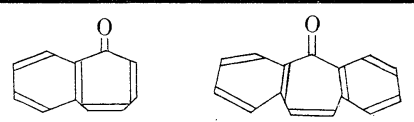

$-0.680$

$-0.636$

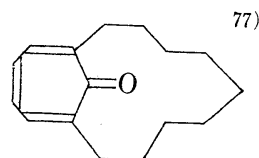

(100)

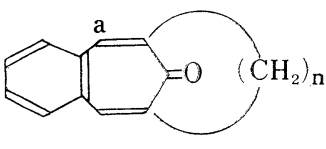

(101)

表 34 ポリメチレン 4,5-ベンゾトロポソ ${ }^{55 d}$

\begin{tabular}{r|r|r|r}
\hline $\mathrm{n}$ & $\begin{array}{c}\nu_{\mathrm{C}=\mathrm{O}}\left(\mathrm{cm}^{-1}\right) \\
(\mathrm{Nujol})\end{array}$ & $\begin{array}{c}\mathrm{Ha} の \mathrm{NMR} \\
\left(\mathrm{CDCl}_{3}, \boldsymbol{\delta}\right)\end{array}$ & $-\mathrm{E}_{1 / 2}$ \\
\hline 0 & 1590 & - & 0.631 \\
4 & 1724 & - & 1.142 \\
5 & 1679 & 6.78 & 1.124 \\
6 & 1651 & - & 0.977 \\
7 & 1609 & 7.2 & - \\
8 & 1604 & - & 0.883 \\
10 & 1610 & 7.27 & - \\
12 & 1590 & 7.52 & 0.828 \\
\hline
\end{tabular}

表 31 トロポン類のカルボニル基の赤外吸収と $\pi$ 結合次数 (HMO) ${ }^{73 b)}$

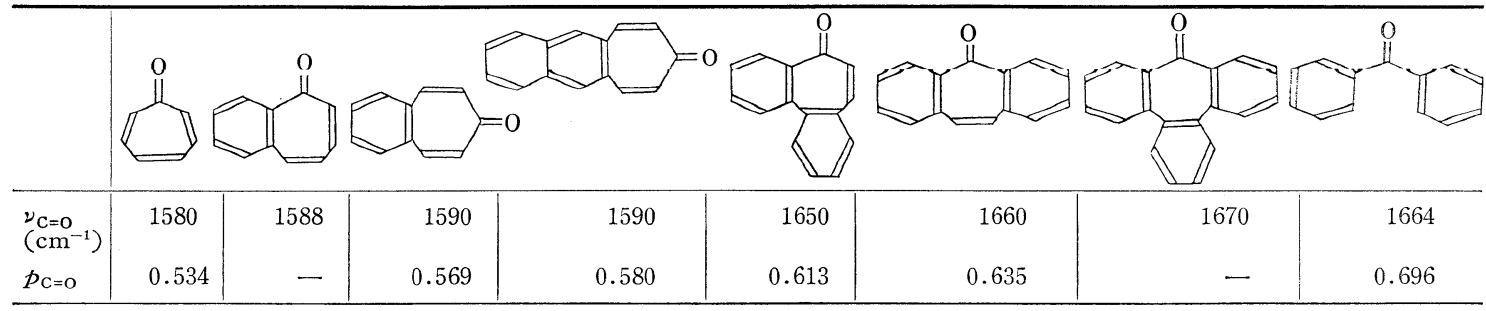


菨 35 ビスポリメチレンビスベソゾトロポソ ${ }^{78)}$

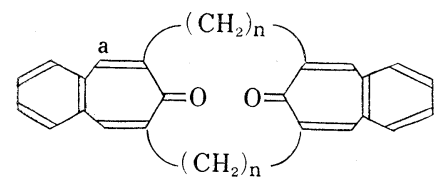

(102)

\begin{tabular}{c|c|c}
\hline $\mathrm{n}$ & $\nu_{\mathrm{C}=\mathrm{O}}\left(\mathrm{cm}^{-1}\right)$ (Nujol) & $\mathrm{Ha}$ の $\mathrm{NMR}\left(\mathrm{CDCl}_{3}, \delta\right)$ \\
\hline 4 & 1595 & 7.0 \\
5 & $\prime \prime$ & 7.1 \\
6 & $\prime \prime$ & - \\
8 & 1605 & 7.4 \\
\hline
\end{tabular}

表 36 ベソゾトロポロン類の $\mathrm{p} K_{\mathrm{a}}{ }^{79)}$

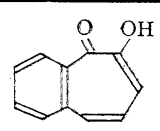

9.5

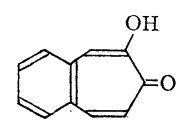

10.0

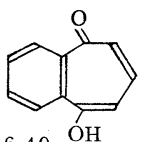

$6.40 \mathrm{OH}$
リフルオロ酢酸中でトロピリウムイオンとなる。

次に単環下ロポノイドとベンゾトロポノイドの化学性 を比較検討して見る。トロポン (77)，トロポロン (79) はそれぞれ双極イオン $\left(77^{\prime}\right)$ と $\left(79^{\prime}\right)$ の寄与があるが, 2,3-ベンゾトロポン (94)，3,4-ベンゾトロポロン (103) はベンゼン型双極イオン $\left(94^{\prime}, 103^{\prime}\right)$ の寄与を主に受け, 不安定なの-キノン型双極イオン $\left(94^{\prime \prime}, 103^{\prime \prime}\right)$ の寄与は ほとんどない。同様に 4,5-ベンゾトロポン (96)，4,5ベンゾトロポロン (104) もベンゼン型双極イオンの寄与 をうけ ーキノン型双極イオンの寄与をうけない。これ が単環性卜ロポノイドとベンゾトロポノイドの化学性が
若干異なる原因である。

たとえばトロポロンはカルボン酸ビニログであるが, 3,4-ベンゾトロポロン(103) は 0 -キノン型の $\left(103^{\prime \prime}\right)$ の 寄与がないからカルボン酸ビニログでない。そのため酸 性が弱い(表 36)。4,5-ベンゾトロポロンも同様な理由で 酸性が弱い。なお, 表 36 において 4-オキシ-2,3-ベンゾ トロポンの酸性が特に強いのはカルボニルと水酸基が共 役の位置にあるためである。トロポロンはカルボン酸と 類似して容易にメチルエーテル（80)，2-クロロトロポ ン（78）になり，これらを加水分解するとトロポロンに 㞍ることを前に述べたが，(103), (104) はカルボン酸ビ ニログでないからジアゾメタンでメチル化困難であり， 塩化チオニルで水酸基を塩素置換することができない。 トロポロンは互変異性混合物（79）」(79a)（998 ペー ジ）として存在するが，(103）は互変異性体（103a）が 不安定な 0 -キノン型であるため互変異性はなく，専ら (103) の型で存在する。同様にして (104) も互変異性が ない。表 33 の 3,4-ベンゾトロポロンの NMR で $\mathrm{J}_{\mathrm{a}, \mathrm{b}}$ $(9.8 \mathrm{~Hz}), \mathrm{J}_{\mathrm{b}, \mathrm{c}}(11.9 \mathrm{~Hz})$ が表 26 のトロポロンメチル エーテルの $\mathrm{J}_{3,4}(10.1 \mathrm{~Hz}) ， \mathrm{~J}_{4,5}(11.0 \mathrm{~Hz})$ のそれぞれ にほぼ等しいことからもベンゾトロポロンに互変異性が ないことがわかる。3,4:5,6-ジベンゾトロポロン(105) はトロポロン誘導体よりもむしろエノロン トン互変異性体であってアセタートを与える(エノル性) 一方，ジオキシム，キノキザリンを与える（ 性)。(単環卜ロポロン，ベンゾトロポロンはケトン試薬 と反応しない。）(105）はアルカリに溶けない。アルカ リと温めると容易にベンジル酸転位（ $\propto$-ジケトン性）を

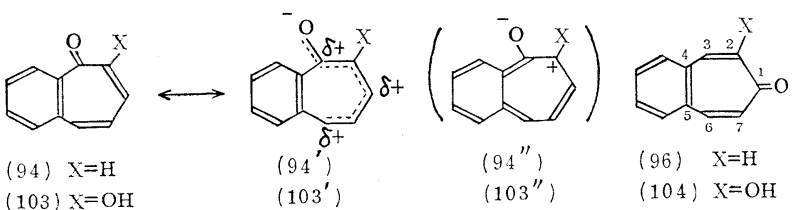

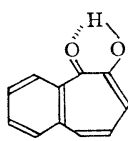

(103)

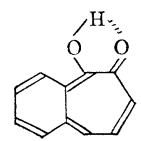

(103 a)

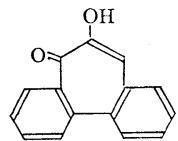

$(105$

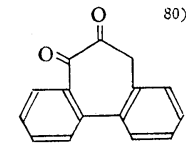

(105 a)

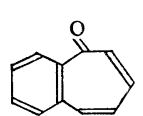

(94)
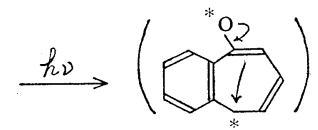

(94a)
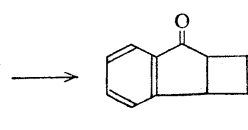

(106) 
起こしてフェナントレン-9-カルボン酸になる。光照射 によりトロポンは二量化しメトキシトロポンは分子内環 化することを前に述べたが，2，3-ベンゾトロポンは光照 射では二量化の他に分子内環化 (106) も起こる。それは ベンゼン核の存在のために, ベンジル位が励起されたも の (94a) が安定となり, これを通って反応が進むためで あろう。その他, ベンゾトロポノイドの詳細な化学反 応 $^{899}$, 光反応 ${ }^{63 b, 90)}$ 亿ついては文献を参照。

3. その他のトロポノイドシクロブタジエン縮環 トロポンの最初の例としてシクロブタジエノトロポン鉄 トリカルボニル (107a) が合成された。NMR (o) は H (5) (5.78), H (6) (6.73), H (7) (6.02), $\mathrm{J}_{5,6}=9.5 \mathrm{~Hz}$, IR $\left(\mathrm{CHCl}_{3}\right)$ は 2060, 1995, 1620,1592, $1520 \mathrm{~cm}^{-1}$ で 金属カルボニル，トロポノイドカルボニルおよびオレフ イン二重結合の吸収を示す。(107a) を加水分解すると トロポロン (107b) になり, また (107a) はトリエチル オキソニウムフルオロボレートと安定な塩 (107c) を作 る。

ジベンゾ〔b,e]トロポン (108) は1つのベンゼン核 が $o$-キノン型に固定されるから不安定な化合物と考え られる。オキシケトン (109) を濃硫酸に溶かすと共役酸 (108a)になり (NMR で確認) 低温で中和すると二量 体になる。二量体を無水マレイン酸と加熱すると (108) の付加体（110）を与える。(108) のフェニル誘導体も 単離できないが溶液中で赤外が測定された $\left(\nu_{\mathrm{C}=\mathrm{O}} 1623\right.$<smiles></smiles><smiles>CCOc1cccc(OCC)c1OCC(=O)OCC#N</smiles>
$\mathrm{J}_{6,7}=13.0 \mathrm{~Hz}$ で単環トロポン（表 19,22 ) に類する。

$\left.\mathrm{cm}^{-1}\right)$ 。(108) のフェニル置換体の 合成も試みられたが 単離されていない。

ベンゾシクロヘプタトリエン-4'-オン (111) はトロポ ン核を持たないが，ベンゾトロポン $(94,96)$ の異性体 であって，ベンゾトロポンと類似の性質が期待される。 Proctor ら ${ }^{83)}$ はこの系統の化合物を研究した。(111) 自 身は不安定で溶液でのみ存在が認められたに過ぎない が，その塩 (111a) は安定である。その 5'-オキシ誘導 体 (112a)（ベンゾトロポロン $(103 ， 104)$ の異性体) は安定で，IR (クロロホルム) 1629, 1603, $1582 \mathrm{~cm}^{-1}$ $(>\mathrm{C}=\mathrm{O},>\mathrm{C}=\mathrm{C}<$ ), $\mathrm{NMR}$ (重ピリジン) $1.7 \sim 3.0 \tau$

(核の $7 \mathrm{H})$ で，ベンゾトロポロン類似の芳香族性があ る。5'-メトキシ体 (112b) も同様である。ジベンゾ $[b, f]$ アゼピン-2-オン (113a) は（111)のへテロアナ ログであるが安定で，IR（ヌジョール）1640，1590， $1550(>\mathrm{C}=\mathrm{O},>\mathrm{C}=\mathrm{C}<), \mathrm{NMR} 2.0 \sim 3.5 \tau$ で，臭素 化，二ト口化すると臭素置換体，(113b)，二ト口置換体 (113c）を生じる。(112) のベンゾログ（114）も合成さ れた。また (113) の類似体 (115) も知られている。

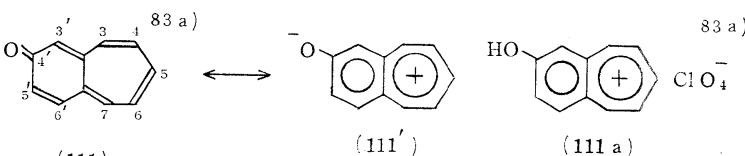

(111)

$\left(111^{\prime}\right)$

(111 a)
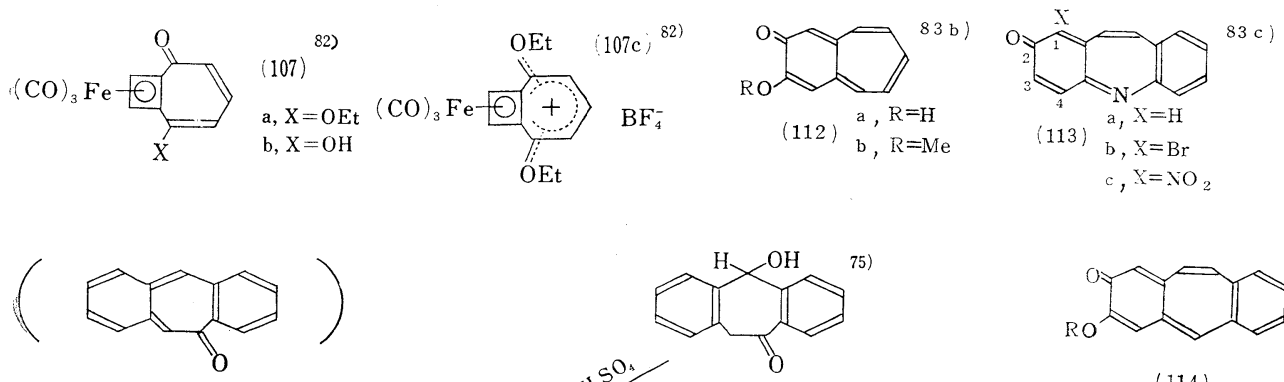

(108)

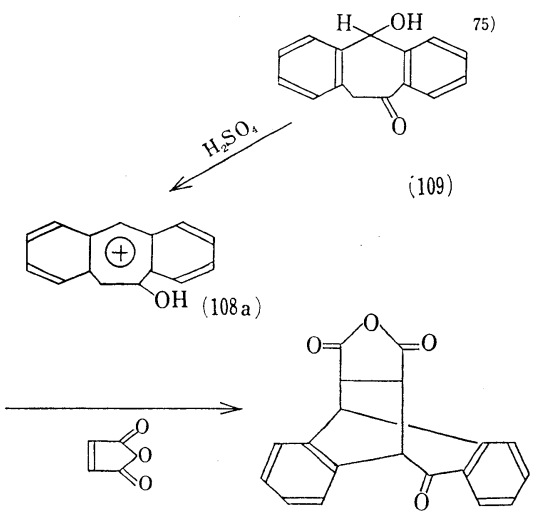

(110)
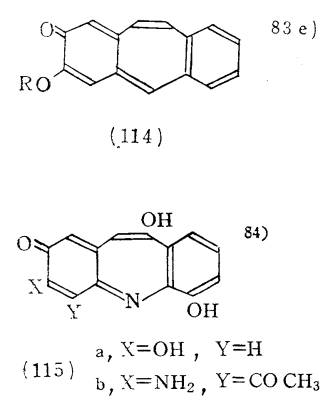

トロポキノン（116）に関しては誘導体 (モノ，ジ，トリオキシム，キノキザロト ロポン $)^{55 \mathrm{e})}$, シベンゾトロポキノン (117) 55g) が以前から知られているが, 母体(116) 
( 23 )

はごく最近合成された ${ }^{85 a)}$ 。 IR はベン ゾキノンに類し, MS は分子イオンピ 一クを与えず，p-ベンゾキノンが基 準ピークとなる。ベンゾインドロトロ ポキノンも合成された ${ }^{86)}$ 。ヘプタトリ アフルバレン-3,4-ジオン (118), 1 , 2-ジオン (119) が合成され, 詳しく 研究された ${ }^{85 \mathrm{~b}, 88 \mathrm{a})}$ 。(118, $\left.\mathrm{X}=\mathrm{Ph}\right)$ の $\mathrm{IR}, \nu_{\mathrm{C}=\mathrm{O}} 1600 \mathrm{~cm}^{-1}$, フェニル基のオ ルト位プロトンとメタパラ位プロト

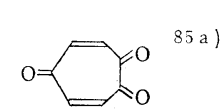

(116)

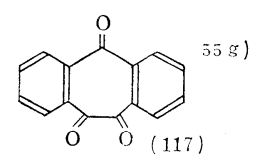

(117)

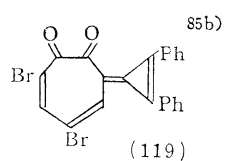

(119)

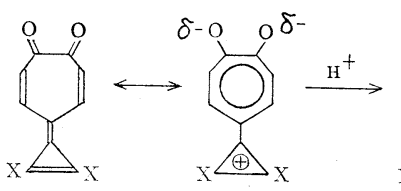

(118)

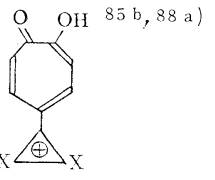

(118 a)

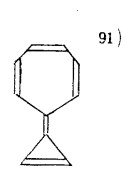

(120)

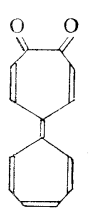

(121)
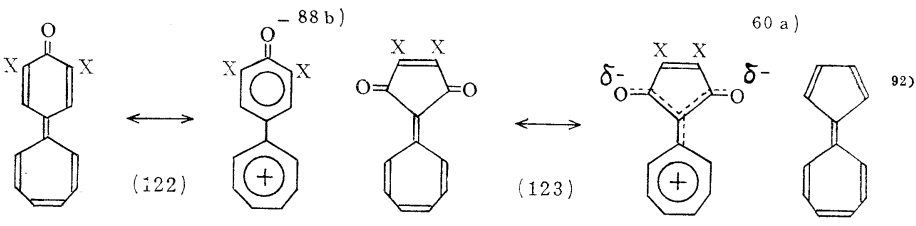

(124)
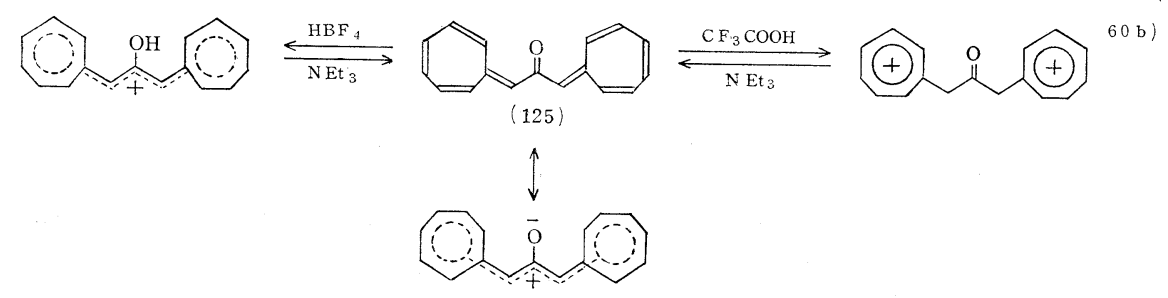

注トロポノイドの合成法(いるいるある)のうち, 比較的最近の方法数例を付記する。

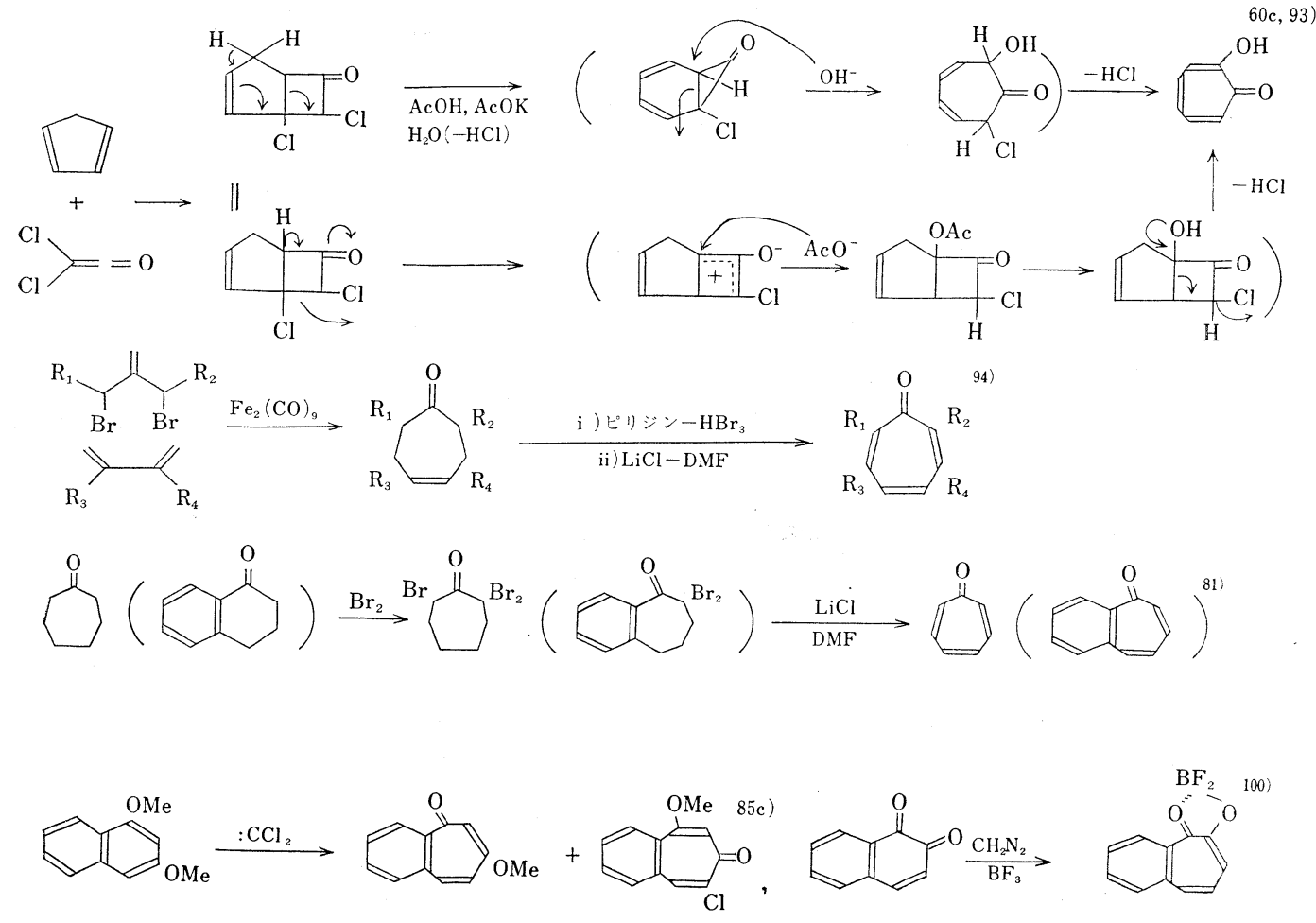


ンの NMR $\delta$ 值の差は $(118, \mathrm{X}=\mathrm{Ph})$ で $0.51 \mathrm{ppm}$, (118a, $\mathrm{X}=\mathrm{Ph})$ で $0.58 \mathrm{ppm}$ で大差がないこと，(118， $\mathrm{X}=\mathrm{H})$ の双極子モーメントの $\mathrm{MO}$ 計算值は大きく 13 . 13D であることなどから，(118'）の寄与が大きいこと が示された。(119) も UV, IR の検討から（118）と類 似構造であることが結論されている。ヘプタフルバレン -3,4-ジオン $(121)^{64 a)}$ も合成された。他にキノントロピ ド(1-オキサ〔1,6,7〕キナレン) $\left.(122)^{88 b}\right)$, セスキフル バレンジオン $(123)^{60 \mathrm{a})}$, ジフルベニルケトン $(125)^{60 \mathrm{~b})}$ も詳しく研究され, 芳香族的構造が示されている。なお, 母体化合物へプタトリアフルバレン $(120)^{91)}$, セスキフ ルバレン $(124)^{92)}$ は不安定であって, 前者は, まだ合成 されていない，後者は合成されている。

\section{VI. シクロオクタトリエンジオン（シクロ オクタテトラエノキノン）と[9]アヌ レノン}

シクロオクタテトラエニルジアニオン (126) は合成さ れ，NMR，UV などから平面芳香族であることが知ら れている。 8 員環ジカチオン型化合物としてはジシクロ

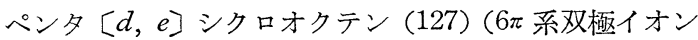
(127') または周辺 $14 \pi$ 共役系 $\left(127^{\prime \prime}\right)$ の寄与が考えら れる) の合成が試みられたが，えられなかった ${ }^{83 \mathrm{~d}) 。 シ ~}$ クロオクタトリエン-1,4-ジオン（シクロオクタテトラ エノ-1,4-キノン) (128) はホモトロポン型 1 価双極イオ ン $\left(128^{\prime}\right)$ または 2 価双極イオン $\left(128^{\prime \prime}\right)$ の寄与のため
$6 \pi$ 芳香族性が考えられる。1,2-ジオン (129) も同様で ある。しかしこれらのジオンはまだ合成されていない。 シクロオクタトリエンジオン誘導体の合成を試みたが 成功しなかったという報告がいくつかある。一例をあげ ると, ジベンゾシクロオクタジエンジオンを酸化してト リオン (130) (エノル型は (130a)) にしようとしたとこ ろ 3 種の生成物 $(131,132,53 \mathrm{~b})$ をえた。(131) は目的の トリオン (130) の水和物であるが, 脱水困難で, 昇華し ても分解せず, 高温に熱すると（130）の分子内アルド 一ル縮合体 (133) になり，目的のトリオン (130) はえら れなかった。次にシクロオクタトリエンジオン誘導体が

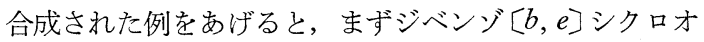
クタトリエン-1,4-ジオン (134) が合成された。芳香族 性の検討はなされなかったが, IR， $\nu_{\mathrm{C}=\mathrm{O}} 1675 \mathrm{~cm}^{-1}$ で普 通の共役ケトンの值であるから芳香族性はないようであ る。次にジベンゾ $[c, g]$ シクロオクタトリエン-1,2-ジ オン $(136)\left(\mathrm{IR}, \nu_{\mathrm{C}=\mathrm{O}} 1715,1667 \mathrm{c} \mathrm{m}^{-1}, \mathrm{NMR}\right.$ オレフィ ンプロトン $\left.\delta 6.83, \mathrm{~J}_{\mathrm{HH}} 12.8, \mathrm{~J}^{13} \mathrm{C}-\mathrm{H} 160 \mathrm{~Hz}\right)$ が合成さ れた。これは対応するモノケトン (135) (IR, $\nu_{\mathrm{C}=\mathrm{O}} 1672$ $\mathrm{cm}^{-1}$, NMR オレフィンプロトン $\delta 6.88, \mathrm{~J}_{\mathrm{HH}} 12.6$, $\mathrm{J}_{13} \mathrm{C}-\mathrm{H} 155,160 \mathrm{~Hz}$ ) と較べて, IR，NMR 共にほとん ど同じであるから，(136）の8 員環はオレフィンであり 2 つのカルボニル振動のカップリングの值から（136a） のような王冠構造をしているものと考えられる。最近置 換基をもつ 2,3-ベンゾシクロオクタトリエン-1,4-ジオ ン (137) と 3,4-ベンゾシクロオクタトリエン-1,2-ジオ
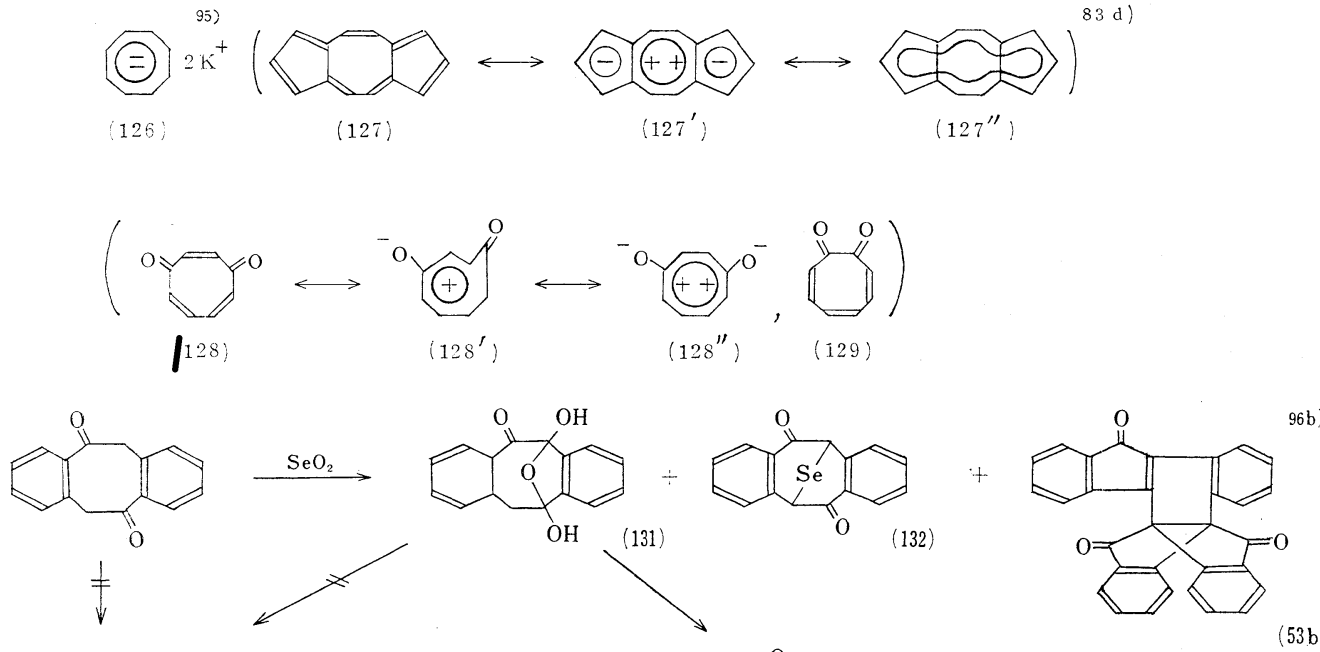

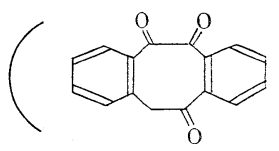

(130)

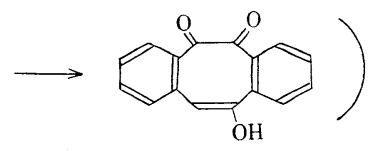

(130a)

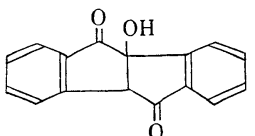

(133)

$96 \mathrm{~b})$ 


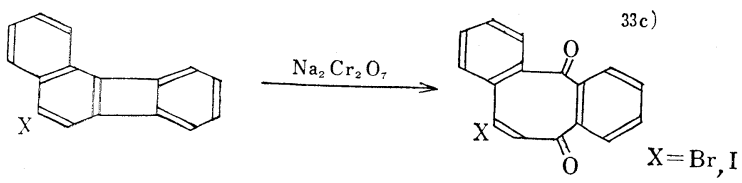

(134)

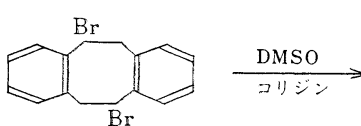

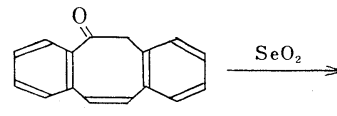

(135)

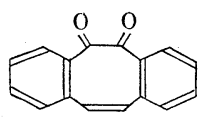

(136)

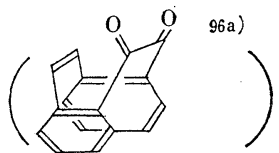

(136a)

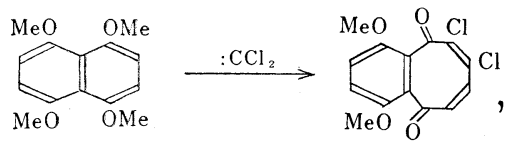

(137)
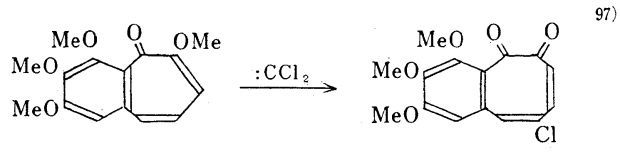

(138)
ン (138) が合成された $1702 \mathrm{~cm}^{-1}, 8$ 員環プロトンの NMR は $\delta 6.39$ で共隹高 く，(138）もほぼ同様な值を示す。ともに 8 員環部が非 平面オレフィンであることを示している。

シクロノナテトラエニルアニオン (137) は $10 \pi$ 電子系 で大きい非局在化エネルギー $(D E=3.5 \beta)$ をもつが, 結合角の歪みや原子価互变異性も考えられる。実際江合 成され, ${ }^{1} \mathrm{H}-\mathrm{NMR} \delta 6.82$ (半值巾 $0.6 \mathrm{~Hz}$ 以下) の一重 線, ${ }^{13} \mathrm{C}-\mathrm{NMR}$ 注ベンゼンよりわずか $19 \mathrm{ppm}$ 高磁場の
二重線 $\left(\mathrm{J}_{13} \mathrm{C}-\mathrm{H}=137 \mathrm{~Hz}\right)$ であることから反磁性環電流 をもつ芳香族と結論された。シクロノナテトラエノンす なわち〔9]アヌレノン（138）はもし平面共役系ならば $8 \pi$ 系反芳香族である。この化合物の合成は試みられた がまだえられていない69a)。ケトン (139) をケタール （140）にし，オゾン分解してジケトン (141)，フェニル リチウムでジオール (142), 次涚水と加水分解をして ジフェニルジベンゾ〔9]アヌレノン (143) が合成され た。この化合物は IR $\left(\mathrm{CHCl}_{3}\right) \nu_{\mathrm{C}=\mathrm{O}} 1605 \mathrm{~cm}^{-1}, \mathrm{NMR}$
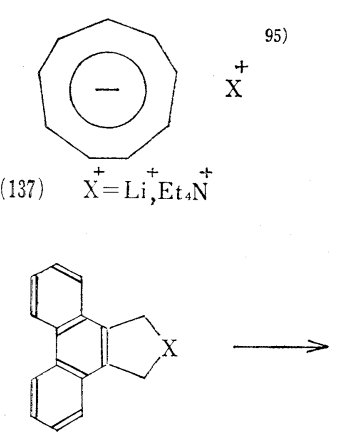

(139) $\mathrm{X}=\mathrm{CO}$

$\left.(140) \mathrm{x}=<_{0}^{0}\right]$

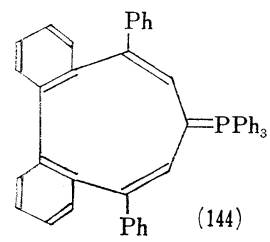

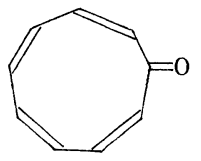

(138)

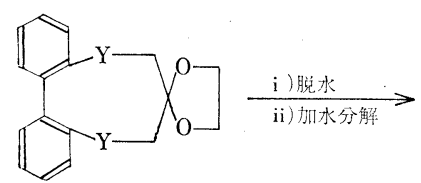

(141) $\mathrm{Y}=\mathrm{CO}$

$(142) \mathrm{Y}=<_{\mathrm{OH}}^{\mathrm{Ph}}$

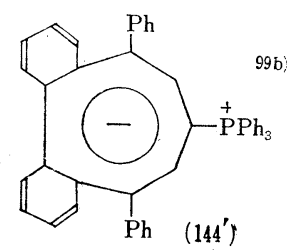

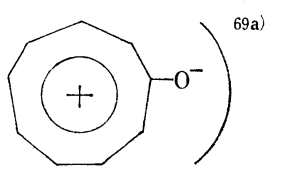

(138́)

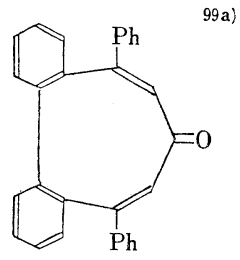

(143) 
$\left(\mathrm{CDCl}_{3}\right) \delta 6.63(2 \mathrm{H}, \mathrm{s}$ ，カルボニルの $\alpha$ 位のH $)$ であ り, シクロノナジエノン, シクロノナトリエノン (IR $\nu_{\mathrm{C}=\mathrm{O}}$ $1610 \sim 1620 \mathrm{~cm}^{-1}$ ，ビニルプロトンの NMR それぞれ $\delta$ $6.83,6.46)^{98)}$ とほぼ同じ值を示すから，このアヌレノ ンは常磁性環電流は認められず非平面ポリエノンであ る。前述のシクロペンタジエンホスホニウムイリド(34) ( ページ) の高級同族体にあたるシクロノナテトラ エンホスホニウムイリド誘導体 $\left.(144)^{99 b}\right)$ も合成された。 この化合物はアルゴン気流中室温で安定，空気中ではす みやかに酸化されてケトン (143) になる。UV の長波長 部吸収は極性溶媒で短波長シフトするから基底状態で極 性イリド構造 $\left(144^{\prime}\right)$ の寄与がある。ただしその程度は シクロペンタジエンイリド (34) の場合より少ない。構 造的にはホスホラン (144) とイリド (144') の中間と考 えられる。

以上において小中員環状アヌレノンの構造と反応性に ついて概説した。読者が非ベンゼン系芳香族化学の一端 を理解するためにいくらかでも役立てば幸いである。こ の表題のもとに取り扱うべき化合物は上記の他にホモ芳 香族アヌレノン(ホモトロポンなど), ヘテロ原子をも つアヌレノン(トロポチオン，へテロ環縮合トロポノイ ドなど）があるが省略した。

(昭和 48 年 7 月 2 日受理)

\section{文献}

1) F. Sondheimer, Accounts Chem. Res. 581 (1972)

2）中島威, 分子科学講座 3 , 分子軌道論 p. 324, 共立出版 (1966)

3a) M.J.S. Dewar, "Molecular Orbital Theory for Org. Chem." McGraw-Hill, N.Y. (1969)

b) M.J.S. Dewar, T. Morita, J. Amer. Chem. Soc. 91802 (1969)

4) R. Zahradnik, J.P. Snyder's “Non-Benzenoid Aromatics" p.1, Academic Press (1971)

5) 黒田睛雄, 有合化 28414 (1970)

6) 小川晴, 伊比井信広, 化学 28 (No. 5), 15 (1973)

7a) A. Krebs, Angew. Chem. 7710 (1965)

b) 吉田善一，宮原英毅，化学 27765 (1972)

8）A. Streitwieser (都野雄甫訳), “分子軌道法” 広 川書店 (1970)

a) p. 257-9. $\quad$ b) p. 269 . c) p. 137 d) p. 416.

9a) R. Breslow, Chem. Eng. News. 43 (26), 90 (1965)

b) R. Breslow, T. Eicher, A. Krebs, R.A. Peterson, J. Posner, J. Amer. Chem. Soc. 87 1320, 1326 (1965)

c) R. Breslow, M. Oda, ibid. 944787 (1972)

d) R. Breslow, M. Oda, J. Pecararo, Tetrahedron Lett. 19724415

e) R. Breslow, Angew. Chem. 80573 (1968) f) R. Breslow, W. Vitale, K. Wendel, Tetrahedron Lett. 1965365

10) R. West, J. Chickos, E. Osawa, J. Amer. Chem. Soc. 903887 (1968)

11) Z. Yoshida, H. Miyahara, Bull. Chem. Soc. Japan 451919 (1972)

12) A. Krebs, B. Schrader, H. Höfler, Tetrahedron Lett. 19685935

13) A. Watanabe, H. Yamaguchi, Y. Amako, H. Azumi, Bull. Chem. Soc. Japan 412196 (1968)

14) D.T. Clark, D.M. Jilley, Chem. Commun. 1970147

15) D.G. Farnum, P.E. Thurston, J. Amer. Chem. Soc. 864206 (1964) ; D.G. Farnum, J. Chickos, P.E. Thurston, ibid. 883075 (1966)

16）清水清争, 宮道一夫, 加藤博史, 米沢貞次, 日化 91206 (1970)

17) N. Turro, W.B. Hammond, J. Amer. Chem. Soc. 883672 (1966)

18) E. Vogel, W. Grimme, S. Korte, Tetrahedron Lett. 19653625

19a) J.H. Bowie, D.W. Cameron, R.G.F. Giles, D.H. Williams, J. Chem. Soc. (B) 1966335

b) J.H. Bowie, D.W. Cameron, D.H. Williams, J. Amer. Chem. Soc. 875094 (1965)

20) J. Zabicky "The Chem. of the Carbonyl Group" Vol. 2, p. 320, Interscience Publishers (1970)

21) B. Willhalm, A.F. Thomas, F. Gautschi, Tetrahedron 201185 (1964)

22) M.S. Ao, E.M. Burgess, A. Schauer, E.A. Taylor, Chem. Commun. 1969220

23) J. Adamson, D.L. Forster, T.L. Gilchrist, C.W. Rees, ibid. 1969221

24) S. Masamune, M. Suda, H. One, L.M. Leichter, ibid. 19721268

25) G.F. Emerson, L. Watts R. Pettit, J. Amer. Chem. Soc. 87131 (1965)

26) H.H. Freeman, A.E. Young, ibid. 86734 (1964)

27a) E.J. Smutny, J.D. Roberts, ibid. 773420 (1955)

b) E.J. Smutny, M.C. Caserio, J.D. Roberts, ibid. 821793 (1960)

28) A.T. Blomguist, E.A. LaLancette, ibid. 831387 (1961); 84220 (1962)

29) J.C. Hinshow, Chem. Commun. 1971630

30) A. Roedig, P. Bernemann, Ann. Chem. 600 1 (1956)

31) G. Maahs, ibid. 68655 (1965)

32a) W. Ried, D. Freitag, Chem. Ber. 99 (8) 2675 (1966)

b) W. Ried, A.H. Schmidt, Angew. Chem. 84 1048 (1972)

33a) M.P. Cava, D.R. Napier, J. Amer. Chem. Soc. 793606 (1957)

b) M.P. Cava, R.J. Pohl, M.J. Mitchell, ibid. 2076,2080 (1963)

c) M.P. Cava, K.W. Ratts, J. Org. Chem. 27752 
(1962)

d) M.P. Cava, M.J. Mitchell, J. Amer. Chem. Soc. 815409 (1959)

34) H.A. Staab, J. Ipaktschi, Tetrahedron Lett. 1966 583; Chem. Ber. 1011457 (1968)

35) D.J. Cram, R.D. Partos, J. Amer. Chem. Soc. 851273 (1963)

36a) C.H. DePuy, E.F. Zaweski, J. Amer. Chem. Soc. 814920 (1959)

b) C.H. DePuy, M. Isaks, K.L. Eilers, G.F. Morris, J. Org. Chem. 293503 (1964)

37a) C.F.H. Allen, J.A. Van Allen, J. Amer. Chem. Soc. 725165 (1950)

b) K. Alder in Forest's "Newer Method of Prep. Org. Chem." Vol, 1, p. 462 3 (1948) Interscience Publ.

38) E.W. Garbisch, R.F. Sprecher, J. Amer. Chem. Soc. 883433 (1966); 916785 (1969)

39a) G. Maier, G. Fritschi, B. Hoppe, Angew. Chem. 82551 (1970)

b) G. Maier, F. Bosslet, Tetrahedron Lett. 1972 1025

40) K. Hafner, K. Wagner, Angezw. Chem. 751104 (1963)

41) G.A. Russell, R.L. Blankespoor, Tetrahedron Lett. 19714573

42) P.H. Lacy, D.C.C. Smith, J. Chem. Soc. 1971 41

43) J.M. Holland, D.W. Jones, ibid. 1971608

44) K. Blatt, R.W. Hoffmann, Angew. Chem. 81 623 (1969)

.45) Rodd's, "Chem. of Carbon Comp." IIIB, p. 1267 (1956), Elsevier Publ Co.

46) E. LeGoff, R.B. Lacount, J. Org. Chem. 33 2529 (1968)

47) H. Hosoya, S. Nagakura, Bull. Chem. Soc. Japan 391414 (1966)

48) D.H. Reid, Quart. Rev. 19274 (1965)

49) R. Pettit, J. Amer. Chem. Soc. 821972 (1960)

.50a) I. Murata, T. Nakazawa, T. Tatsuoka, Tetrahedron Lett. 19711789

b) I. Murata, K. Yamamoto, T. Hirotsu, M. Morioka, ibid. 1972331

c) I. Murata, K. Yamamoto, T. Hirotsu, ibid. 19723389

d) I. Murata, K. Yamamoto, Chem. Lett. 1973413

e) 村田一郎，化学の領域 23 (No.6) p. 21 (1969)

51) V. Boekelheide, C.D. Smith, J. Amer. Chem. Soc. 883950 (1966)

52) W.K. Gibson, D. Leaver, J.E. Roff, C.W. Cumming, Chem. Commun. 1967214

53) E. Galantay, H. Agahigian, N. Paolella, $J$. Amer. Chem. Soc. 883875 (1966)

:54a）阿部憲孝，守田忠義，高瀬 嘉平，第 4 回非ベン ゼン系芳香族化学討論会予稿集（昭 46）p. 96

b) M. Yasunami, K. Takase, T. Nozoe, Tetrahe- dron Lett. 19704327

55）野副鉄男編, “非ベンゼン系芳香族化合物”大有機 化学 13 巻 (昭 45,6 版) 朝倉書店, a) p.75. b) p. 111 . c) p. 138 d) p. 82 e) p. 274,277 , 600. f) p. 182 . g) p. 414

56) D. Ginsberg's, "Non-Benzenoid Arom. Compds." (1959) Interscience Publishers, a) p. 27; b) p. 22 ; c) p. 380

57) T. Nozoe in "International Symposium on the Chem. of Non-Benzenoid Arom. Compds., Specially Invited. Lectures." (Sendai,' 1970), p. $239 \sim 280$

58) D.R. Burnham, M.J. Cook, Tetrahedron Lett. 19683771

59a) D.J. Bertelli, J.T. Gerig, J.M. Herbelin, J. Amer. Chem. Soc. 90107 (1968)

b) D.J. Bertelli, T.G. Andrews, ibid. 915280 (1969)

c) D.J. Bertelli, T.G. Andrews, P.O. Crews, ibid. 915286 (1969)

60a) Y. Kitahara, I. Murata, T. Asao, Bull. Chem. Soc. Japan 34589 (1961), 37924 (1964)

b) M. Yagihara, Y. Kitahara, Chem. Lett. 1972 653

c) T. Asao, T. Machiguchi, T. Kitamura, Y. Kitahara, Bull. Chem. Soc. Japan 432662 (1970)

d）蛭田恵子，今成司，後藤興日，上原忠夫，北原 喜男，第 10 回 NMR 討論会講演予稿集， p. 51 (1971)

e) Y. Kitahara, I. Murata, S. Katagiri, Bull. Chem. Soc. Japan 371399 (1964)

61) M. Traetteberg, J. Amer. Chem. Soc. 864265 (1964)

62a) M.J. Barrow, O.S. Mills, Chem. Commun. 197366

b) M.J. Barrow, O.S. Mills, ibid. 1971119

63a) E.J. Forbes, M.J. Gregory, T.A. Hamar, D.J. Watkin, ibid. 1966114

b) E.J. Forbes, J. Griffiths, R.A. Ripley, $J$. Chem. Soc. (C) 1968 572,575,1149

64) International Symposium on the Chem. of Non-Benzenoid Arom. Compds, Preprints (Sendai, 1970)

a) K. Takahashi, T. Goto, K. Moue, S. Kagabu, K. Takase, p. 13

b) T. Nozoe, T. Hirai, T. Kobayashi, J. Tsunetsugu, p. 227

65a) Y. Ikegami, S. Seto, Bull. Chem. Soc. Japan. 412225 (1968); Y. Ikegami, H. Watanabe, S. Seto, ibid. 451976 (1972); Y. Ikegami, H. Watanabe, S. Seto, Chem. Lett. 1972877

b) Y. Ikegami, S. Seto, ibid. 1973155

c) Y. Ikegami, Bull. Chem. Soc. Japan 361118 (1963)

66a) H. Shimanouchi, Y. Sasada, Tetrahedron 
Lett. 19702421

b) K. Ibata, T. Hata, H. Shimanouchi, Y. Sasada, Chem. Commun. 1972339

c) H. Shimanouchi, T. Hata, Y. Sasada, Tetrahedron Lett. 1968 3573; 1969753

67) H. Kuroda, T. Kuni, Theoret. Chim. Acta. 7 220 (1967)

68) L. Weiler, Can. J. Chem. 501975 (1972)

69a) O.L. Chapman, J. Meinwald, J. Org. Chem. 2362 (1958)

b) O.L. Chapman, C.L. McIntosh, Chem. Commun. 1971770

c) O.L. Chapman, T.H. Kinstle, M.T. Sung, $J$. Amer. Chem. Soc. 882618 (1966)

d) O.L. Chapman, J.D. Lassila, ibid. 902449 (1968)

e) D.K. Koch, S.L. Smith, O.L. Chapman, ibid. 852616 (1963)

f) O.L. Chapman, D.J. Pasto, ibid. 823642 (1960)

70a) S. Ito, Y. Fukazawa, Tetrahedron. Lett. 1972 741,745

b) H. Sugiyama, S. Ito, T. Nozoe, ibid. 1965179

71a) 向井利夫, 有機光化学（化学の領域増刊 93 号, 昭 45) 南江堂, p. 61

b) T. Mukai, T. Nakazawa, T. Shishido, Tetrahedron Lett. 19672465

72) A.S. Kende. Z. Goldschmidt, P.I. Izzo, J. Amer. Chem. Soc. 91 6856,6858 (1969)

73）ヒュッケル分子軌道法 (桜井, 竹内訳), 広川書 店（昭 48）a） p. 354，b）p. 262

74) R. Steward, M.K. Ganger, R.B. Moodie, L.J. Muenster, Can. J. Chem. 411065 (1963)

75) N.L. Bauld, Y.S. Rim, J. Amer. Chem. Soc. 89179 (1967)

76) W. Tochtermann, C. Degel, G.H. Schmidt, Chem. Ber. 1051431 (1972)

77) T. Hiyama, Y. Ozaki, H. Nozaki, Chem. Lett. 1972963

78) R.E. Harmon, R. Suder, S.K. Gupta, J. Chem. Soc. (Perkin Trans.) $\mathbf{1 9 7 2} 1746$

79) P.L. Pauson, Chem. Rev. 5515 (1955)

80) T. Sakan, M. Nakazaki, J. Inst. Polytechnic Osaka City Univ. 11123 (1950)

81a) E.W. Collington, G. Jones, Chem. Commun. 1968958

b) E.W. Collington, G. Jones, J. Chem. Soc. (C) 19692656

82) W. Roberts, A. Wissner, J. Amer. Chem. Soc. 926382 (1970)

83a) A.M. Khan, G.R. Proctor, L. Rees, J. Chem. Soc. (C) 1966990

b) G.R. Proctor, A.H. Renfrew, ibid. 19681187 c) K.E. Haque, K.M. Hardie, G.R. Proctor, $J_{\text {。 }}$ Chem. Soc. (Perkin Trans.) 1972539

d) D. McIntyre, G.R. Proctor, L. Rees, J. Chem. Soc. 1966985

e) G.R. Proctor, A.H. Renfrew, J. Savage, ibid. 19691000

84) A. Butenandt, E. Biekert, G.N. Neubert, Ann. 603200 (1957)

85）第 5 回非ベンゼン系芳香族化学討論会講演予稿集 (1972)

a) 東海林美和，阿部直道，竹下斉，伊東椒， p. 81

b）森田和良, 高橋かず子, 高瀬嘉平 p. 120 .

c）佐藤勝, 恒次丈介, 海老根誠治, p. 112 .

d) 村田一郎, 山本景祚, 広津敏博, p. 133.

86）藤森邦秀, 山根亀治, 日化 28 春季年会予稿集 III, p. 1169 (1973)

87) A.C. Day, M.A. Ledlie, Chem. Commun. 1970 1265

88a) K. Takahashi, T. Fujita, K. Takase, Tetrahedron Lett. 1971 4507, 19722227

b) K. Takahashi, T. Nozoe, Bull. Chem. Soc. Japan 40 1462,1473 (1967)

89) S. Ebine, ibid. 35 114,117, 122,1101 (1962), 382029 (1965) ; M. Hoshino, S. Ebine, ibid. 41 2942,2949 (1968), 431778 (1970), 443480 (1971)

90) M. Yoshioka, I. Saito, M. Hoshino, S. Ebine, Chem. Commun. 1970782 ; M. Yoshioka, M. Hoshino, Tetrahedron Lett. 19712413

91) H. Yamaguchi, T. Nakajima, Theoret. Chim. Acta. 12349 (1968)

92) H. Prinzbach, W. Rosswog, Angew. Chem. 73 169, 543 (1961)

93) P.D. Bartlett, USP 3,448, 155 (1969); P.D. Bartlett, T. Ando, J. Amer. Chem. Soc. 92 7518 (1970) ; H.C. Stevens, D.A. Reich, D.R. Brandt, K.R. Fountain, E.J. Gaughan, ibid. 87 5257 (1965)

94) R. Noyori, S. Makino, H. Takaya, Tetrahedron Lett. 19731745

95) T.J. Katz, J. Amer. Chem. Soc. 82 3784,3785 (1960)

96a) P. Yates, E.G. Lewars, P.H. McCabe, Can. J. Chem. 48788 (1970)

b) P. Yates, E.G. Lewars, ibid. 48796 (1970)

97) J. Tsunetsugu, M. Sato, S. Ebine, Chem. Commun. 1973363

98) J. Ciabattoni, G.H. Berchthold, J. Org. Chem. 311336 (1966)

99a) M. Rabinovitz, F.D. Bergmann, A. Gazit, Tetrahedron Lett. 1971267

b) M. Rabinovitz, A. Gazit, ibid. 19723361

100) M. Sato, J. Tsunetsugu, S. Ebine, Bull. Chem. Soc. Japan 45638 (1972) 